\title{
A 2-decade (1988-2009) record of diatom fluxes in the Mauritanian coastal upwelling: impact of low-frequency forcing and a two-step shift in the species composition
}

\author{
Oscar E. Romero ${ }^{1,2}$, Simon Ramondenc ${ }^{1,2}$, and Gerhard Fischer ${ }^{1,3}$ \\ ${ }^{1}$ MARUM - Center for Marine Environmental Sciences, University of Bremen, Leobener Str. 8, Bremen 28359, Germany \\ ${ }^{2}$ Alfred Wegener Institute, Helmholtz Centre for Polar and Marine Research, \\ Am Alten Hafen 26, Bremerhaven 27568, Germany \\ ${ }^{3}$ University of Bremen, Geosciences Department, Klagenfurter Str., Bremen 28359, Germany
}

Correspondence: Oscar E. Romero (oromero@marum.de)

Received: 9 September 2020 - Discussion started: 13 October 2020

Revised: 13 February 2021 - Accepted: 16 February 2021 - Published: 18 March 2021

\begin{abstract}
Eastern boundary upwelling ecosystems (EBUEs) are among the most productive marine regions in the world's oceans. Understanding the degree of interannual to decadal variability in the Mauritania upwelling system is crucial for the prediction of future changes of primary productivity and carbon sequestration in the Canary Current EBUE as well as in similar environments. A multiyear sediment trap experiment was conducted at the mooring site $\mathrm{CBmeso}$ ("Cape Blanc mesotrophic", ca. $20^{\circ} \mathrm{N}$, ca. $20^{\circ} 40^{\prime} \mathrm{W}$ ) in the highly productive coastal waters off Mauritania. Here, we present results on fluxes of diatoms and the speciesspecific composition of the assemblage for the time interval between March 1988 and June 2009. The temporal dynamics of diatom populations allows the proposal of three main intervals: (i) early 1988-late 1996, (ii) 1997-1999, and (iii) early 2002-mid 2009. The Atlantic Multidecadal Oscillation (AMO) appears to be an important driver of the longterm dynamics of diatom population. The long-term AMOdriven trend is interrupted by the occurrence of the strong 1997 El Niño-Southern Oscillation (ENSO). The extraordinary shift in the relative abundance of benthic diatoms in May 2002 suggests the strengthening of offshore advective transport within the uppermost layer of filament waters and in the subsurface and in deeper and bottom-near layers. It is hypothesized that the dominance of benthic diatoms was the response of the diatom community to the intensification of the slope and shelf poleward undercurrents. This dominance followed the intensification of the warm phase
\end{abstract}

of AMO and the associated changes of the Atlantic Meridional Overturning Circulation. Transported valves (siliceous remains) from shallow Mauritanian coastal waters into the bathypelagic should be considered for the calculation and model experiments of bathy- and pelagic nutrients budgets (especially $\mathrm{Si}$ ), the burial of diatoms, and the paleoenvironmental signal preserved in downcore sediments. Additionally, our 1988-2009 data set contributes to the characterization of the impact of low-frequency climate forcings in the northeastern Atlantic and will be especially helpful for establishing the scientific basis for forecasting and modeling future states of the Canary Current EBUE and its decadal changes.

\section{Introduction}

As part of the latitudinally extended eastern boundary upwelling ecosystem (EBUE) of the Canary Current (CC) in the subtropical northeastern Atlantic, the Mauritanian upwelling is characterized by intense offshore Ekman transport and strong mesoscale heterogeneity. This physical setting facilitates the vigorous exchange between the neritic and pelagic realms off Mauritania (Chavez and Messié, 2009; Freón et al., 2009; Cropper et al., 2014). The nutrient trapping efficiency of upwelling cells (Arístegui et al., 2009), the input of wind-carried dust particles from the Sahara and the Sahel (Romero et al., 1999b, 2003; Friese et al., 2017; Fischer et al., 
2016, 2019), and/or the wide shelf (Hagen, 2001; Cropper et al., 2014) additionally impact the intensity of the primary production in surface waters and the subsequent export of microorganism remains into the meso- and bathypelagic off Mauritania. This set of conditions varies strongly on different temporal patterns (from seasonal through decadal; Mittelstaedt, 1983, 1991; Hagen, 2001; Nykjær and Van Camp, 1994; Barton et al., 2013; Varela et al., 2015). Whether the strong interannual and decadal variability of physical conditions off Mauritania is related to low-frequency, global-scale climatic variations or to an intrinsic level of basin-wide atmospheric and/or oceanic variability is still a matter of debate (Cropper et al., 2014; Varela et al., 2015; Fischer et al., 2016, 2019).

EBUEs may prove more resilient to ongoing climate change than other ocean ecosystems because of their ability to function under extremely variable conditions (Barton et al., 2013; Varela et al., 2015). On the other hand, it is predicted that current global warming will impact atmospheric pressure gradients and hence the strength of coastal winds that cause upwelling (Bakun, 1990; Bakun et al., 2010). Although productivity variations in EBUEs are sensitive to the amplitude and timing of upwelling-favorable winds (Varela et al., 2015), the impact of ongoing ocean warming on the dynamics of upwelling-favorable winds is still contentious (Bakun, 1990; Bakun et al., 2010; Varela et al., 2015). Longterm trends in variations in upwelling intensity and related productivity changes seem highly dependent on the length of the data series, the selected study area, the season evaluated, and the methods applied (Varela et al., 2015). The description of multiyear to interdecadal trends of upwelling intensity in the CC EBUE has been mostly based on variations in velocity and direction of winds and calculated upwelling intensities. Cropper et al. (2014) found a non-significant increase in upwelling-favorable winds along the CC EBUE between 11 and $35^{\circ} \mathrm{N}$. Using the same database as Cropper et al. (2014), Narayan et al. (2010) and Patti et al. (2010) analyzed the annual wind stress over 4 decades and found significant increasing trends across $24-32^{\circ} \mathrm{N}$. Contradictory results were also obtained using Ekman transport data. GómezGesteira et al. (2008) detected a significant decreasing trend in upwelling intensity across $20-32^{\circ} \mathrm{N}$ for all seasons between 1967 and 2006, while Pardo et al. (2011) found a general weakening of upwelling intensity between 10 and $24^{\circ} \mathrm{N}$ for the time interval 1970-2009. Barton et al. (2013) found no statistically significant change of the annual mean wind intensity off northwest Africa over the second half of the 20th century.

A different approach for the characterization of multiyear to interdecadal trends in EBUEs is assessing fluxes of particulates and microorganisms as captured by continuous sediment trap experiments. This study builds on earlier investigations of multiyear variability of the diatom flux captured with sediment traps deployed at the mesotrophic mooring site CBmeso (Cape Blanc mesotrophic, formerly known as
CB, Fig. 1; Fischer et al., 1996). Several earlier studies addressed either the variations in marine diatom fluxes between March 1988 and November 1991 (Romero et al., 1999a, 2002; Romero and Armand, 2010; Lange et al., 1998) or the land-derived signal of siliceous remains (Romero et al., 1999b, 2003). After a gap of 2.5 years (December 1991 through May 1994), the CBmeso trap experiment re-started in June 1994 (Table 1). Here, we extend the diatom record collected from early June 1994 until middle June 2009. The main goal of this study is the description of the multiyear dynamics of the total diatom flux and the shifts in the speciesspecific composition of the assemblage at the site CBmeso during almost 20 years (1988-2009). Our study presents the longest sediment-trap-based time series on the temporal dynamics of diatom fluxes in the world ocean. We discuss the new results in view of the high frequency of climate indices, which are proxies for atmospheric and hydrographic dynamics along the CC EBUE, and low-frequency climate variability in the North Atlantic, and we compare our new data set at the site CBmeso with previous diatom (Romero and Fischer, 2017; Lange et al., 1998; Romero et al., 1999a, b, 2002, 2020) and bulk flux results off Mauritania (Helmke et al., 2005; Fischer et al., 2016, 2019). We also discuss our new results with recent results from the nearby coastal site $\mathrm{CBeu}$ (Cape Blanc eutrophic) (Romero and Fischer, 2017; Romero et al., 2020).

\section{Material and methods}

\subsection{Mooring location, sampling intervals, and sample treatment}

A total of 20 moorings were deployed off Mauritania (Fig. 1) between March 1988 and June 2009. Details on sampling intervals and trap depths are given in Table 1. Major gaps in the diatom record are between (i) December 1991 and June 1994 (no traps deployed), (ii) October 1994 and November 1995 (malfunctioning of the trap CBmeso6 upper), (iii) October 1997 and June 1998 (malfunctioning of the trap CBmeso8 upper), and November 1999 and March 2001 (malfunctioning of traps CBmeso10 and 11 lower) (Table 1). The entire study interval extended over $7734 \mathrm{~d}$ between March 1988 and June 2009. During this interval, samples were collected for $5574 \mathrm{~d}$. The gaps that occurred total $2160 \mathrm{~d}$ of the entire trap experiment.

We used deep-moored (>700 $\mathrm{m}$ water depth), largeaperture time-series sediment traps of the Kiel and Honjo types with 20 cups and $0.5 \mathrm{~m}^{2}$ openings, equipped with a honeycomb baffle (Kremling et al., 1996). As the traps were moored below intermediate water masses (CB1lower: $2195 \mathrm{~m}$; CB2-5, 7, 9-12, 15-20lower: 3502-3633 m; and CB6, 8 and 14upper: 745-1246m, Table 1), uncertainties with the trapping efficiency due to strong currents (e.g., undersampling) and/or due to the migration and activity of zoo- 


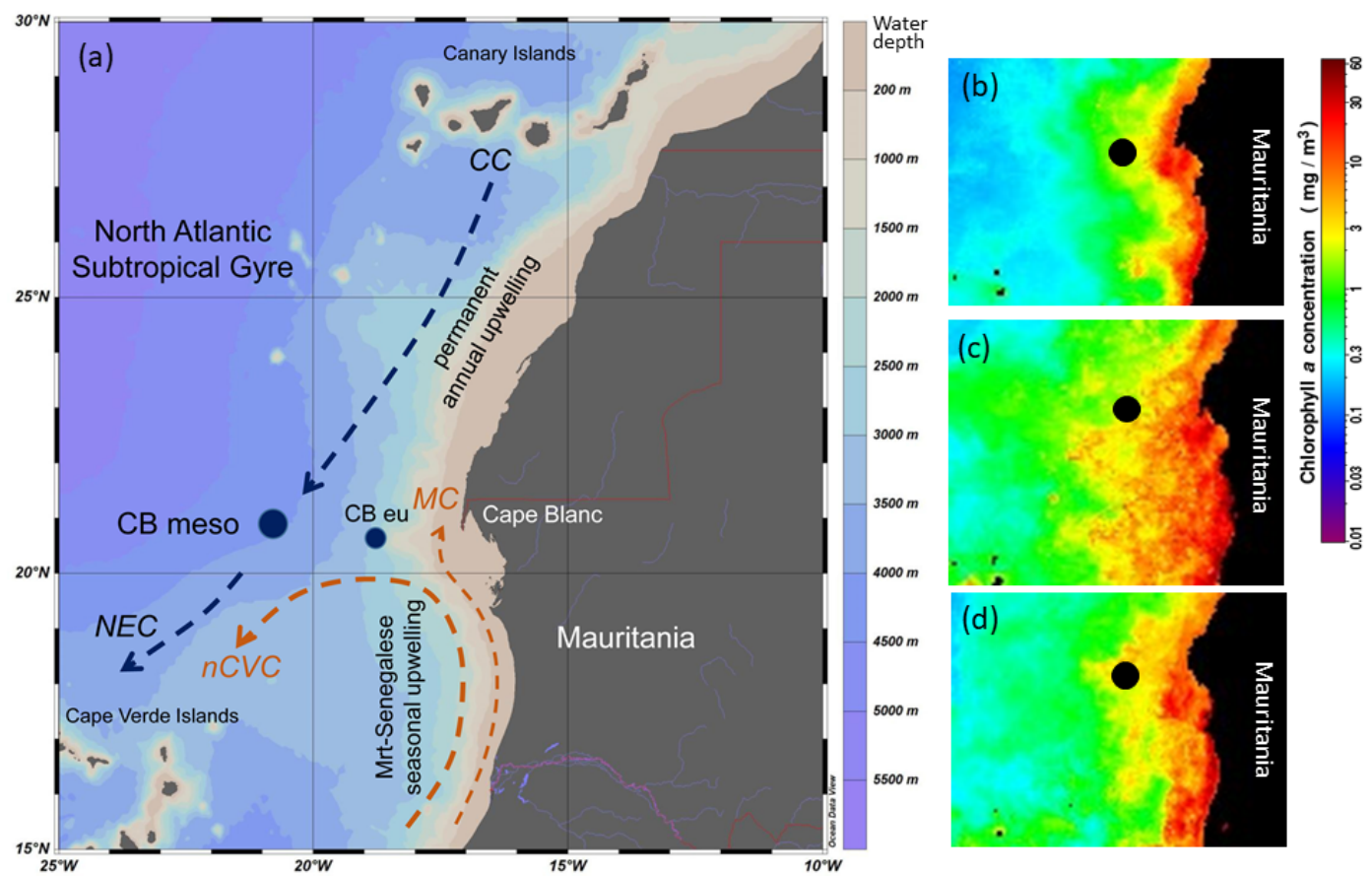

Figure 1. (a) Map of the study area showing the locations of the sediment trap sites CBmeso and CBeu (dark blue dots). Major surface currents are also shown (Canary Current: CC; Mauritanian Current: MC; North Equatorial Current: NEC; north Cabo Verde Current: nCVC). The upwelling zones along the northwestern African margin are depicted after Cropper et al. (2014). The color scale (right-hand side) refers to meters below surface water $(0 \mathrm{~m})$. (b-d) Satellite-gained images of average winter concentration of chlorophyll $a$ in surface waters along the northwestern African margin. The images depict chlorophyll $a$ values in winters 1997, 2002, and 2008, gained with SeaWIFs (b, 1997) and MODIS (c and d, 2002 and 2008; https://oceancolor.gsfc.nasa.gov/cgi/13, last access: 31 July 2020). Note the high interannual variability of chl $a$ concentration. For interpretation of the references to color in this figure legend, the reader is referred to the web version of this article.

plankton migrators ("swimmer problem") are assumed to be minimal (Buesseler et al., 2007). Prior to the deployments, the sampling cups were poisoned with $\mathrm{HgCl}_{2}$ (1 $\mathrm{mL}$ of conc. $\mathrm{HgCl}_{2}$ per $100 \mathrm{~mL}$ of filtered seawater), and pure $\mathrm{NaCl}$ was used to increase the density in the sampling cups to $40 \%$. Upon recovery, samples were stored at $4{ }^{\circ} \mathrm{C}$ on board and wet-split in the home laboratory (MARUM, University of Bremen) using a rotating McLane splitter system. Larger swimmers - such as crustaceans - were handpicked at the home lab by using forceps and were removed by filtering the sample carefully through a $1 \mathrm{~mm}$ sieve. All flux data here refer to the size fraction $<1 \mathrm{~mm}$. In almost all samples, the fraction of particles $>1 \mathrm{~mm}$ was negligible (larger pteropods were found only in a few samples; Fischer et al., 2016).

We compare our data with those previously published at the mooring location $\mathrm{CBeu}$ (ca. $20^{\circ} 45^{\prime} \mathrm{N}, 18^{\circ} 45^{\prime} \mathrm{W}$ ), also deployed off Mauritania (Romero and Fischer, 2017; Romero et al., 2020). It locates ca. 80 nautical miles $(\sim 150 \mathrm{~km})$ offshore over the continental slope in ca. $2750 \mathrm{~m}$ water depth. For site CBeu, only the upper trap fluxes are shown (Romero and Fischer, 2017; Fischer et al., 2019; Romero et al., 2020).

\subsection{Assessment of diatom fluxes and species identification}

The $1 / 64$ and $1 / 125$ splits of the original samples were used. Samples were rinsed with distilled water and prepared for diatom studies following standard methods (Schrader and Gersonde, 1978). For this study, a total of 282 sediment trap samples were processed. Each sample was chemically treated with potassium permanganate, hydrogen peroxide (33\%), and concentrated hydrochloric acid (32\%) following previously used methodology (Romero and Fischer, 2017; Romero et al., 1999a, b, 2002, 2009a, b, 2020). Qualitative and quantitative analyses of the diatom community were carried out on permanent slides of acid-cleaned material (Mountex ${ }^{\circledR}$ mounting medium) at $\times 1000$ magnification by using a Zeiss ${ }^{\circledR}$ Axioscope with phase-contrast illumination (MARUM, University of Bremen). Depending on valve abundances in each sample, several traverses across each slide were examined. The counting procedure and definition of counting units for valves follow Schrader and Gersonde (1978). The total number of counted valves per slide ranged between ca. 400 and 1000. Two cover slips per sample were scanned in this way. Counts of valves in replicate 
Table 1. Data deployment at the site CBmeso (Cape Blanc mesotrophic): trap name, coordinates (latitude and longitude), ocean bottom depth, trap depth, sampling interval, and sample amount.

\begin{tabular}{|c|c|c|c|c|c|c|c|c|}
\hline \multirow[t]{2}{*}{ Trap name } & \multirow{2}{*}{$\begin{array}{l}\text { Lat } \\
\mathrm{N}\end{array}$} & \multirow{2}{*}{$\begin{array}{l}\text { Long } \\
\text { W }\end{array}$} & \multirow{2}{*}{$\begin{array}{c}\text { Bottom } \\
\text { depth } \\
\text { m }\end{array}$} & \multirow{2}{*}{$\begin{array}{r}\text { Trap } \\
\text { depth } \\
m\end{array}$} & \multicolumn{2}{|c|}{ Sampling } & \multirow{2}{*}{$\begin{array}{r}\text { No. of } \\
\text { samples }\end{array}$} & \multirow{2}{*}{$\begin{array}{l}\text { Diatom data } \\
\text { previously published by }\end{array}$} \\
\hline & & & & & start & end & & \\
\hline CBmeso1 lower & $20^{\circ} 45.3^{\prime}$ & $19^{\circ} 44.5^{\prime}$ & 3646 & 2195 & 22 Mar 1988 & 8 Mar 1989 & 13 & $\begin{array}{l}\text { Lange et al. (1998), } \\
\text { Romero et al. (2002) }\end{array}$ \\
\hline CBmeso2 lower & $21^{\circ} 08.7^{\prime}$ & $20^{\circ} 41.2^{\prime}$ & 4092 & 3502 & 15 Mar 1989 & 24 Mar 1990 & 22 & Romero et al. (2002) \\
\hline CBmeso3 lower & $21^{\circ} 08.3^{\prime}$ & $20^{\circ} 40.3^{\prime}$ & 4094 & 3557 & 29 Apr 1990 & 8 Apr 1991 & 17 & Romero et al. (2002) \\
\hline CBmeso4 lower & $21^{\circ} 08.7^{\prime}$ & $20^{\circ} 41.2^{\prime}$ & 4108 & 3562 & 3 Mar 1991 & 19 Nov 1991 & 13 & Romero et al. (2002) \\
\hline CBmeso5 lower & $21^{\circ} 08.6^{\prime}$ & $20^{\circ} 40.9^{\prime}$ & 4119 & 3587 & 6 Jun 1994 & 27 Aug 1994 & 19 & \\
\hline CBmeso6 upper* & $21^{\circ} 15.0^{\prime}$ & $20^{\circ} 41.8^{\prime}$ & 4137 & 771 & 2 Sep 1994 & 16 Oct 1994 & 2 & \\
\hline CBmeso7 lower & $21^{\circ} 15.4^{\prime}$ & $20^{\circ} 41.8^{\prime}$ & 4152 & 3586 & 20 Nov 1995 & 29 Jan 1997 & 20 & \\
\hline CBmeso8 upper* & $21^{\circ} 16.3^{\prime}$ & $20^{\circ} 41.5^{\prime}$ & 4120 & 745 & 30 Jan 1997 & 4 Jun 1998 & 8 & \\
\hline CBmeso9 lower & $21^{\circ} 15.2^{\prime}$ & $20^{\circ} 42.4^{\prime}$ & 4121 & 3580 & 11 Jun 1998 & 7 Nov 1999 & 20 & \\
\hline CBmeso12 lower* & $21^{\circ} 16.0^{\prime}$ & $20^{\circ} 46.5^{\prime}$ & 4145 & 3610 & 5 Apr 2001 & 17 Dec 2001 & 14 & \\
\hline CBmeso13 lower & $21^{\circ} 16.8^{\prime}$ & $20^{\circ} 46.7^{\prime}$ & 4131 & 3606 & 23 Apr 2002 & 8 May 2003 & 20 & \\
\hline CBmeso14 upper & $21^{\circ} 17.2^{\prime}$ & $20^{\circ} 47.6^{\prime}$ & 4162 & 1246 & 31 May 2003 & 2 Nov 2003 & 10 & \\
\hline CBmeso15 lower & $21^{\circ} 17.9^{\prime}$ & $20^{\circ} 47.8^{\prime}$ & 4162 & 3624 & 17 Apr 2004 & $21 \mathrm{Jul} 2005$ & 20 & \\
\hline CBmeso16 lower & $21^{\circ} 16.8^{\prime}$ & $20^{\circ} 47.8^{\prime}$ & 4160 & 3633 & $25 \mathrm{Jul} 2005$ & 28 Sep 2006 & 20 & \\
\hline CBmeso17 lower & $21^{\circ} 16.4^{\prime}$ & $20^{\circ} 48.2^{\prime}$ & 4152 & 3614 & 24 Oct 2006 & 25 Mar 2007 & 20 & \\
\hline CBmeso18 lower & $21^{\circ} 16.9^{\prime}$ & $20^{\circ} 48.1^{\prime}$ & 4168 & 3629 & 25 Mar 2007 & 5 Apr 2008 & 20 & \\
\hline CBmeso19 lower & $21^{\circ} 16.2^{\prime}$ & $20^{\circ} 48.7^{\prime}$ & 4155 & 3617 & 22 Apr 2008 & 22 Mar 2009 & 20 & \\
\hline CBmeso20 lower* & $21^{\circ} 15.6^{\prime}$ & $20^{\circ} 50.7^{\prime}$ & 4170 & 3620 & 3 Apr 2009 & 12 Jun 2009 & 4 & \\
\hline
\end{tabular}

* Traps with malfunctioning, having caused gaps in the diatom record.

slides indicate that the analytical error of valve concentration estimates is $\leq 10 \%$.

The resulting counts yielded abundance of individual diatom taxa as well as daily fluxes of valves $\mathrm{m}^{-2} \mathrm{~d}^{-1}$ (DF), calculated according to Sancetta and Calvert (1988), as follows:

$\mathrm{DF}=\frac{[N] \times[A / a] \times[V] \times[\text { Split }]}{[\text { days }] \times[D]}$,

where $[N]$ is number of valves in a known area $[a]$ as a fraction of the total area of a petri dish $[A]$ and the dilution volume $[V]$ in milliliters. This value is multiplied by the sample split [Split], representing the fraction of total material in the trap, and then divided by the number of [days] of sample deployment and the sediment trap collection area $[D]$.

\subsection{Statistical analysis}

Correspondence analysis (CA) was used to explore diatom communities' changes. CA is an ordination technique that enables description of the community structure from multivariate contingency tables with frequency-like data (i.e., abundances derived from counting with integers and zeros) that are dimensionally homogeneous (Legendre and Legendre, 2012). Based on the CA samples' scores, a hierarchical clustering analysis was performed to classify the samples' date according to the diatom composition similarities. Euclidean distance was used to compute the distance matrix from which a hierarchical dendrogram was gener- ated using Ward's aggregation link (Legendre and Legendre, 2012). This approach has been computed by using the vegan package included in the R software. In addition, KruskalWallis tests, coupled with multiple comparison tests (pairwise Wilcoxon rank sum test), have been performed on climatic indexes and total diatom flux according to sample groups highlighted by the clustering analysis with the aim of identifying relationships between environmental forcing indices and diatom communities.

\section{Physical setting of the study area}

\subsection{Oceanography, winds, and upwelling dynamics}

The CC EBUE is in the eastern part of the North Atlantic subtropical gyre (Fig. 1, Chavez and Messié, 2009; Arístegui et al., 2009; Cropper et al., 2014). Both the temporal occurrence and the intensity of the upwelling along northwestern Africa depend on the shelf width, seafloor topography, wind direction and strength (Mittelstaedt, 1983; Hagen, 2001), Ekman-mediated transport, and mesoscale heterogeneity (Chavez and Messié, 2009; Fréon et al., 2009; Cropper et al., 2014). The Mauritanian shelf is wider than the shelf northward and southward along the CC EBUE and gently slopes from the coastline into water depths below $200 \mathrm{~m}$ (Hagen, 2001). The shelf break zone with its steep continental slope extends over approximately $100 \mathrm{~km}$ from the coast- 
line (Hagen, 2001). Because of the coastal topography, shelf and slope bathymetry, ocean currents, and wind system, surface waters off Mauritania are characterized by almost permanent upwelling with varying intensity year-round (Lathuilière et al., 2008; Cropper et al., 2014). The site CBmeso locates at the westward end of this permanent upwelling zone.

The surface hydrography off Mauritania is influenced by two major surface currents: the southwestward-flowing $\mathrm{CC}$ and the poleward-flowing coastal countercurrent or Mauritania Current (MC) (Fig. 1). The surficial CC detaches from the northern African continental slope between 25 and $21^{\circ} \mathrm{N}$ and supplies Si-poor waters to the North Equatorial Current. CC waters are relatively cool because it entrains upwelled water from the coast as it moves southward (Mittelstaedt, 1991). The Si-rich MC gradually flows northward along the coast up to about $20^{\circ} \mathrm{N}$ (Mittelstaedt, 1991) and brings warmer surface waters from the equatorial realm into waters overlying the site CBmeso. Towards late autumn, the MC is gradually replaced by a southward flow associated with upwelling water due to the increasing influence of trade winds south of $20^{\circ} \mathrm{N}$ (Zenk et al., 1991) and becomes a narrow strip of less than $100 \mathrm{~km}$ wide in winter (Mittelstaedt, 1983). The MC advances onto the shelf in summer and is enhanced by the relatively strong Equatorial Countercurrent and the southerly trade winds (Mittelstaedt, 1983).

North of Cape Blanc (ca. $21^{\circ} \mathrm{N}$; Fig. 1), the intense northeasterly winds cause coastal upwelling to move further offshore and the upper slope fills with upwelled waters. South of Cape Blanc, northerly winds dominate year-round, but surface waters remain stratified, and the coastal Poleward Undercurrent (PUC) occurs as a subsurface current (Pelegrí et al., 2017). South of Cape Timiris (ca. 19³0' N), the PUC intensifies during summer-fall and remains at the subsurface during winter-spring (Pelegrí et al., 2017). The convergence of the northward-flowing MC-PUC system with the southward-flowing currents builds the Cabo Verde Frontal Zone (Zenk et al., 1991; Fig. 1), and the large offshore water export is visible as the giant Mauritanian chlorophyll filament (Gabric et al., 1993; Pelegrí et al., 2006, 2017).

The chlorophyll filament extends offshore up to $400 \mathrm{~km}$ (e.g., Arístegui et al., 2009; Cropper et al., 2014; Van Camp et al., 1991; Fig. 1b-d), carrying a mixture of North and South Atlantic Central Water (NACW and SACW, respectively) through an intense offshore jet-like flow (Meunier et al., 2012). Intense offshore transport acts as an important mechanism for the export of cool, nutrient-rich shelf and upper-slope waters. It has been estimated that this giant filament exports about $50 \%$ of the coastal new production toward the open ocean during intervals of the most intense upwelling (Gabric et al., 1993; Lange et al., 1998; Van Camp et al., 1991; Helmke et al., 2005). This transport impacts even more distant regions in the deep ocean, since sinking particles are strongly advected by lateral transport in subsurface and deeper waters (Fischer and Karakaş, 2009; Karakaş et al., 2006; Fischer et al., 2009).
The SACW occurs in layers between 100 and $400 \mathrm{~m}$ depth around the Banc d'Arguin and off Mauritania. The hydrographic properties of upwelled waters over the shelf suggest that they ascend from depths between 100 and $200 \mathrm{~m}$ south off the Banc d'Arguin (Mittelstaedt, 1983). North of the Banc d'Arguin, the SACW merges gradually into deeper layers (200-400 m) below the CC (Mittelstaedt, 1983). The biological response is accelerated in upwelled waters when the SACW of the upper part of the undercurrent feeds the onshore transport of intermediate layers to form mixed-water types on the shelf (Zenk et al., 1991).

\subsection{Large-scale, low-frequency climate and oceanographic modes potentially affecting the Mauritanian upwelling area}

\subsubsection{Atlantic Multidecadal Oscillation (AMO)}

The AMO is the average of sea surface temperatures (SSTs) of the North Atlantic Ocean (from 0 to $60^{\circ} \mathrm{N}, 80^{\circ} \mathrm{W}$ to $0^{\circ}$ ), detrended to isolate the natural variability (Endfield et al., 2001). It is an ongoing series of multidecadal cyclicity, with cool and warm phases that might last between 20 and 40 years with a difference of about $15^{\circ} \mathrm{C}$ between extremes. These changes are natural and have been occurring for at least the last 1000 years. Since AMO is linked to SST variations, it also plays a significant role in the decadal forcing of productivity changes (O'Reilly et al., 2016). Fischer et al. (2016) state that the correlation of sea level pressure with area-averaged $\left(0-70^{\circ} \mathrm{N}, 60-10^{\circ} \mathrm{W}\right)$ SST fluctuations over periods longer than 10 years highlights a center of action in the tropical Atlantic with sea level pressure reductions (weaker northeasterly winds) along with higher Atlantic Basin-wide sea level pressure during a positive AMO phase. This shows the importance of longer-term, Atlantic basin-scale SST variations for alongshore winds and upwelling trends at the site CBmeso.

Despite the indirect role of the atmosphere, the physical connection between the Atlantic Meridional Overturning Circulation (AMOC) and the AMO is typically described in terms of oceanic processes alone: since the AMOC transports heat northward over the entire Atlantic, an increase in North Atlantic Deep Water (NADW) formation should increase the strength of the AMOC, thus increasing oceanic meridional heat transport convergence in the North Atlantic, resulting in a basin-scale warming of SSTs (Knight et al., 2005). AMOC variability itself is often attributed to changes in NADW formation due to anomalous Arctic freshwater fluxes (Jungclaus et al., 2005) and/or atmospheric modes such as the North Atlantic Oscillation (NAO; e.g., Buckley and Marshall, 2016). In contrast, Clement et al. (2015) found that the pattern of AMO variability can be reproduced in a model that does not include ocean circulation changes but only the effects of changes in air temperature and winds. 


\subsubsection{El Niño-Southern Oscillation (ENSO) and La Niña}

ENSO is an irregularly periodic variation in winds and SST over the tropical eastern Pacific Ocean that affects the climate of much of the tropics and subtropics of other ocean basins via teleconnections. The warming phase is known as El Niño and the cooling phase as La Niña. The Southern Oscillation is the accompanying atmospheric component, coupled with the SST variations. ENSO-related teleconnections in the CC EBUE upwelling system have been described by several authors (Behrenfeld et al., 2001; Pradhan et al., 2006; Zeeberg et al., 2008) and can be illustrated by the negative correlation of sea level pressure with eastern tropical Pacific SST.

The relationship between ENSO and other low-frequency forcings is still uncertain. It has been hypothesized that AMO could influence ENSO on multidecadal timescales (Dong et al., 2006); however, due to the comparatively low record of observations, the relationship between ENSO and other modes of multidecadal variability could just be random (e.g., Wittenberg, 2009; Stevenson et al., 2012). Levine et al. (2017) observed that AMO modifies the thermocline in the tropical Pacific, which, in turn, affects ENSO variance. Zhang et al. (2019) found that the negative ENSONAO correlation in late boreal winter is significant only when ENSO and AMO are in phase, while no significant ENSOdriven atmospheric anomalies are observed over the North Atlantic when ENSO and the AMO are out of phase. ENSO exhibits a considerable degree of diversity in its pattern of SST anomalies, which also complicates its connection with NAO. All these factors may increase the uncertainty of the ENSO-NAO relationship (Zhang et al. (2019) and references therein).

\subsubsection{North Atlantic Oscillation}

The NAO characterizes the difference of atmospheric sea level pressure between the Icelandic Low and the Azores High (Hurrell, 1995). These fluctuations control the strength and direction of westerly winds and location of storm tracks across the North Atlantic. A positive phase of the NAO is associated with anomalous high pressure in the Azores High region and stronger northeasterly winds along the NW African coast. Especially from November through April, the NAO is responsible for much of the weather variability in the North Atlantic region, affecting wind speed and wind direction changes, changes in temperature and moisture distribution, and the intensity, number, and track of storms.

As for ENSO, links between NAO and other lowfrequency forcings remain debatable. Yamamoto and Palter (2016) show that some relation exists between NAO and AMO, with northerly winds associated with a positive state of AMO and zonal winds to a negative state of AMO. Winter correlations show that NAO and ENSO may have opposite
Table 2. Estimates of annual total diatom fluxes. Values were calculated for those calendar years with at least $300 \mathrm{~d} \mathrm{yr}^{-1}$ of trap collection.

\begin{tabular}{llrr}
\hline Year & Interval & $\begin{array}{c}\text { Number } \\
\text { of days } \\
(n)\end{array}$ & $\begin{array}{r}\text { Annual total } \\
\text { diatom flux }\end{array}$ \\
& & $\begin{array}{r}\text { valves per square meter } \\
\text { per year) }\end{array}$ \\
\hline 1988 & 22 Mar-31 Dec & 303 & 375396364 \\
1989 & 1 Jan-31 Dec & 365 & 213264682 \\
1990 & 1 Jan-31 Dec & 365 & 209400523 \\
1991 & 1 Jan-31 Dec & 365 & 137419778 \\
1996 & 1 Jan-31 Dec & 365 & 91909532 \\
1997 & 1 Jan-28 Oct & 300 & 26149573 \\
2001 & 4 Mar-31 Dec & 302 & 45141069 \\
2002 & 23 Apr-31 Dec & 252 & 55852514 \\
2003 & 1 Jan-2 Nov & 305 & 214578146 \\
2005 & 1 Jan-31 Dec & 365 & 260635121 \\
2006 & 1 Jan-31 Dec & 365 & 75713333 \\
2007 & 1 Jan-31 Dec & 365 & 108216786 \\
2008 & 1 Jan-31 Dec & 366 & 183759846 \\
\hline
\end{tabular}

effects on wind fields in the CC EBUEs and consequently on upwelling, with potential implications for the magnitude of deep-ocean mass fluxes (Fischer et al., 2016).

\section{Results}

\subsection{Total diatom fluxes}

Marine diatoms are the main contributors to the siliceous fraction in samples collected with the CBmeso traps between March 1988 and June 2009. Silicoflagellates and radiolarians are secondary components of the siliceous fraction (data not shown here), with a minor contribution of land-derived freshwater diatoms and phytoliths. In terms of number of individuals, the total diatom flux was always 1 order to 4 orders of magnitude higher than that of the other siliceous organisms.

The total diatom flux ranged from $2.7 \times 10^{3}$ to $3.3 \times$ $10^{6}$ valves per square meter per day (average $=4.0 \times$ $10^{5}$ valves $\pm 4.4 \times 10^{5}$ ) and shows strong interannual variability (Fig. 2, Table 2). The highest fluxes $\left(>1.0 \times 10^{6}\right.$ valves per square meter per day) occurred in 1988 , late 1989 , early 2002, 2003, late 2004, early 2005, early 2007, and early 2008. The lowest total diatom flux was recorded between 1997 and $1999\left(\right.$ range $\left.=2.3 \times 10^{3}-5.1 \times 10^{4}\right)$.

Maxima of total diatom flux are defined here as those values that are higher than the total diatom flux average \pm 1 standard deviation (SD) for the entire study period. Fluxes in spring and summer show the highest number of abovethe-average values. Although the same number of total diatom flux maxima is recorded in fall as in summer and spring $(n=17)$, the absolute values of fall maxima were predomi- 


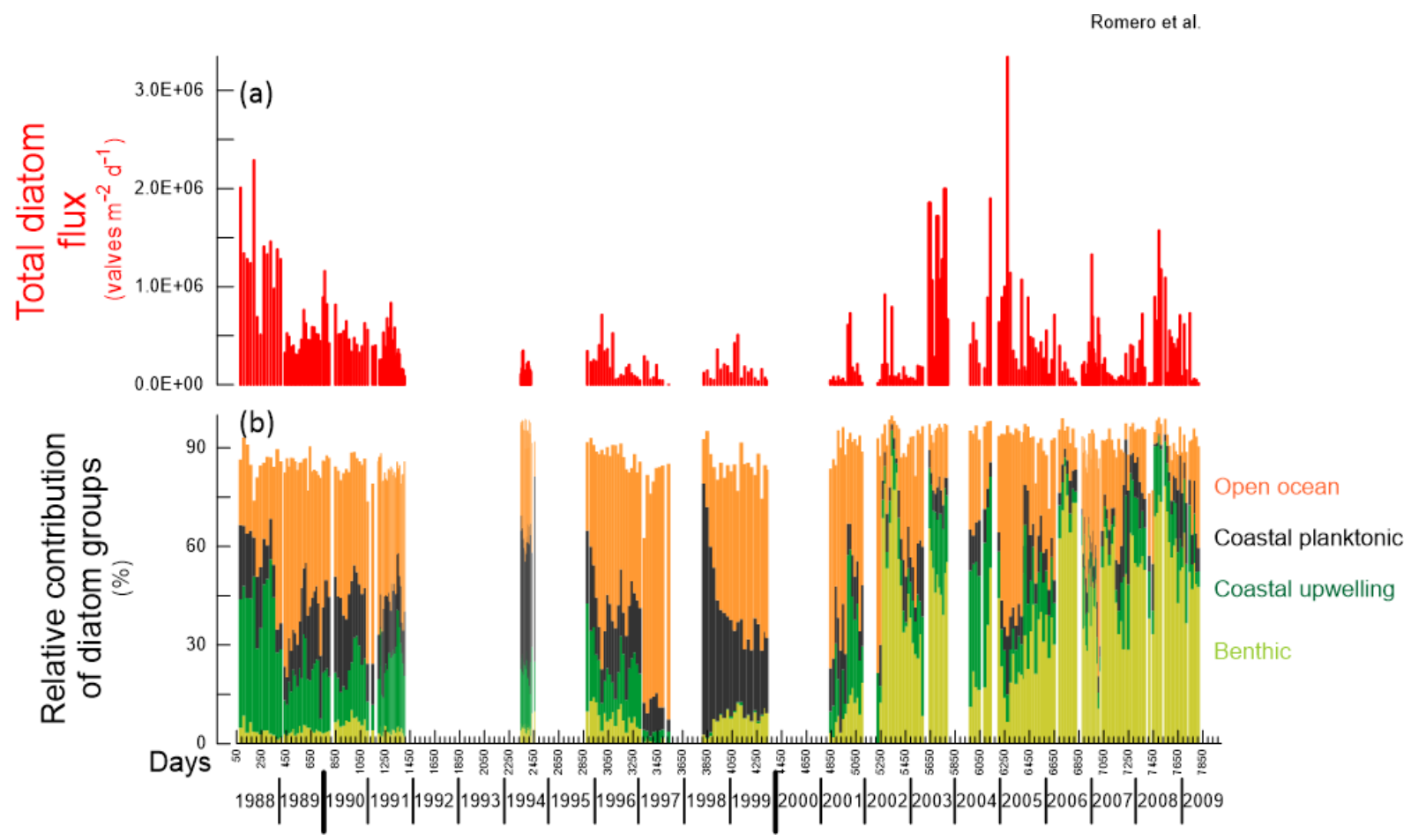

Figure 2. Total diatom flux (valves per square meter per day) and relative contribution of diatom groups (relative contribution, \%) for the interval from March 1998 to June 2009 at the CBmeso site. Groups of diatoms are benthic (light green), coastal planktonic (black), coastal upwelling (dark green), and open ocean (orange). For the species-specific composition of each group, see Sect. 4.2. and Table 2. For interpretation of the references to color in this figure legend, the reader is referred to the web version of this article.

nantly lower than those of spring and summer. Winter has the lowest number of total diatom flux maxima $(n=12)$.

Estimates of annual diatom fluxes were calculated for calendar years with at least $250 \mathrm{~d} \mathrm{yr}^{-1}$ of flux collections. Data are presented in Table 2 . Values range between $3.8 \times 10^{8}$ and $2.6 \times 10^{7}$ valves per square meter per year $(1 \mathrm{SD}=$ $1.0 \times 10^{8}$ valves per square meter per year; average $=1.5 \times$ $10^{8}$ valves per square meter per year). Values above the average occurred in 1988-1990, 2003, 2005, and 2008. The lowest value was recorded in 1997 (Table 2).

\subsection{Temporal variations in marine diatom populations}

A total of 203 diatom species were identified in CBmeso samples between March 1988 and June 2009. To better understand the temporal variations in the diverse community, we follow the same grouping approach as already applied in the nearby trap site CBeu (Romero and Fischer, 2017; Romero et al., 2020). Out of 203 taxa, 109 species (whose average relative contribution is $\geq 0.50 \%$ for the entire studied interval) were distributed in four groups, according to the main ecological and/or habitat conditions they represent: (1) benthic, (2) coastal upwelling, (3) coastal planktonic, and (4) open-ocean diatoms. Taxa assigned to each group are listed in Table 3 and described below.
1. The benthic group is dominated by Delphineis surirella. As part of the epipsammic community, D. surirella is a benthic marine species that commonly thrives in the shallow euphotic zone of sandy shores and shelf and uppermost-slope waters along temperate to cool seas, forming either short or long chains of small valves (length $=5-15 \mu \mathrm{m})$ (Andrews, 1981).

2. The coastal upwelling group is composed of several species of Chaetoceros resting spores (RSs) and the vegetative cells of Thalassionema nitzschioides var. nitzschioides. Both taxa are common components of the coastal and hemipelagic upwelling assemblages in EBUEs (Romero and Armand, 2010; Nave et al., 2001; Abrantes et al., 2002; Romero et al., 2002). Vegetative cells of numerous Chaetoceros species (mainly those assigned to the section Hyalochaete; Rines and Hargraves, 1988) rapidly respond to the weakening of upwelling intensity and nutrient depletion by forming endogenous resting spores; hence their high numbers in trap samples are interpreted to represent the strongest upwelling intensity (Romero and Armand, 2010; Nave et al., 2001; Abrantes et al., 2002; Romero et al., 2002).

3. Coastal planktonic species mostly thrive in neritic to hemipelagic and oligo- to mesotrophic waters with moderate levels of dissolved silica (DSi). These species 
(a)

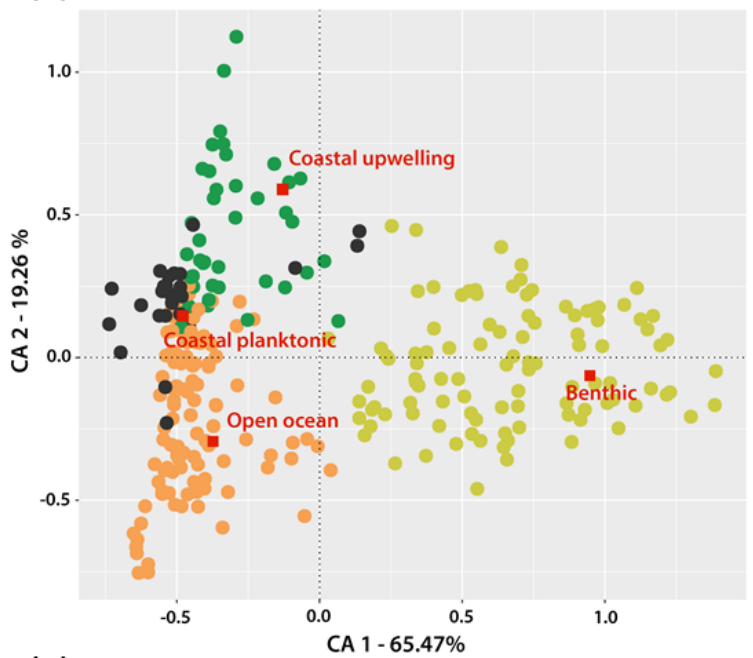

(b)

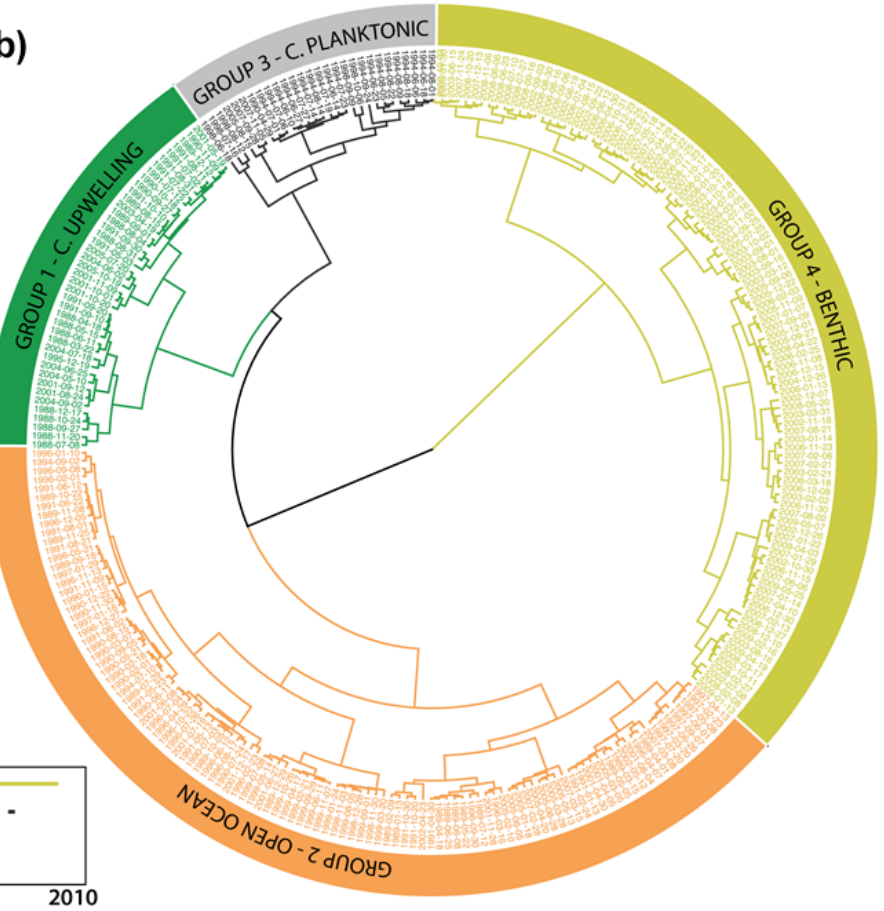

Figure 3. (a) Correspondence analysis (CA) of diatom groups found at the CBmeso site between March 1988 and June 2009, coupled with (b) a hierarchical clustering analysis of samples' score resulting from CA (see Sect. 2.3). Note that in (a) the red squares for each group represent the centroid of dates and their placement within the corresponding group. The corresponding group's name is written in red. (c) The time series of the four diatom groups identified by both multivariate analyses (CA and clustering) is also represented. Colors used for identifying each diatom group are the same as in Fig. 2b. Euclidean distance and Ward's aggregation link were used to perform the hierarchical dendrogram. For the species-specific composition of each group, see Sect. 4.2. and Table 2. For interpretation of the references to color in this figure legend, the reader is referred to the web version of this article.

become more abundant during intervals of decreased mixing, when upwelling weakens (Romero and Armand, 2010; Romero and Fischer, 2017; Romero et al., 2009a, b, 2020; Crosta et al., 2012). The well-silicified species Actinocyclus curvatulus, Cyclotella litoralis, Coscinodiscus radiatus, and Shionodiscus oestrupii var. venrickae are the main contributors at the CBmeso site.

4. Open-ocean taxa thrive in pelagic, oligotrophic, and warm to temperate waters with low siliceous productivity due to low DSi availability and weak mixing in surface waters (Romero and Fischer, 2017; Nave et al., 2001; Romero et al., 2005; Crosta et al., 2012). The term "low DSi" availability $\left(<5 \mu \mathrm{mol} \mathrm{kg}{ }^{-2}\right)$ is used in comparison to the "high DSi" availability in coastal waters of EBUEs, which is at least 4 to 10 times higher than in open-ocean waters of the mid-latitude North Atlantic (Ragueneau et al., 2000). The highly diverse group of open-ocen taxa are dominated by several species of Azpeitia, together with Fragilariopsis doliolus, Nitzschia bicapitata, Nitzschia interruptestriata, Roperia tesselata, and Planktoniella sol.

The multivariate analyses performed on the relative abundance of diatom populations (Fig. 3) confirm the strong in- terannual variability, with significant shifts within the diatom community between 1988 and 2009. The first CA component covers $65.47 \%$ of the total variance and opposes the samples dominated by benthic and coastal planktonic diatoms (Fig. 3a). The second CA axis explains $19.16 \%$ of the total variance and discriminate coastal upwelling and openocean diatoms. The clustering analysis allows the samples to be statistically grouped, and the complete time series was segmented according to the four diatom communities' affiliation (Fig. 3b). These clusters show clear changes of diatom populations' contribution throughout the time series (Fig. 3c) with the dominance of open-ocean and costal upwelling populations between 1988 and 1996. Open-ocean diatoms dominated from 1997 to 2001, while benthic taxa were main contributors from 2002 to 2009.

A major shift in the relative contribution of the diatom groups is seen from May 2002 onward. This shift occurred in two steps (Figs. 2b and 3c). The percentage of benthic diatoms strongly increased between the middle of May and the middle of June 2002 (increase from $12.5 \%$ to $68.6 \%$; trap CBmeso13, samples 2 and 3, 12 May to 19 June 2002). Benthic diatom contribution decreased below $40 \%$ in early 2004 . A second increase occurred in winter 2006, with values being 
Table 3. Species composition of the assemblage of diatoms at the site CBmeso between March 1988 and June 2009.

\begin{tabular}{|c|c|c|c|}
\hline & Group & Species & Main References \\
\hline 1. & Benthic & $\begin{array}{l}\text { Actinoptychus senarius } \\
\text { Actinoptychus vulgaris } \\
\text { Biddulphia alternans } \\
\text { Cocconeis spp. } \\
\text { Delphineis surirella } \\
\text { Diploneis spp. } \\
\text { Gomphonema spp. } \\
\text { Odontella mobiliensis } \\
\text { Paralia sulcata } \\
\text { Psammodyction panduriformis } \\
\text { Rhaphoneris amphiceros } \\
\text { Tryblionella spp. }\end{array}$ & $\begin{array}{l}\text { Andrews (1981), Round et al. (1990), } \\
\text { Hasle and Syvertsen (1996) }\end{array}$ \\
\hline 2. & Coastal upwelling & $\begin{array}{l}\text { Chaetoceros affinis } \\
\text { Chaetoceros cinctus } \\
\text { Chaetoceros compressus } \\
\text { Chaetoceros constrictus } \\
\text { Chaetoceros coronatus } \\
\text { Chaetoceros debilis } \\
\text { Chaetoceros diadema } \\
\text { Chaetoceros radicans } \\
\text { Thalassionema nitzschioides var. nitzschioides }\end{array}$ & $\begin{array}{l}\text { Hasle and Syvertsen (1996), Abrantes } \\
\text { et al. (2002), Nave et al. (2001), } \\
\text { Romero et al. (2002), Romero and } \\
\text { Armand (2010) }\end{array}$ \\
\hline 3. & Coastal planktonic & $\begin{array}{l}\text { Actinocyclus curvatulus } \\
\text { Actinocyclus octonarius } \\
\text { Actinocyclus subtilis } \\
\text { Azpeitia barronii } \\
\text { Chaetoceros concavicornis (vegetative cell) } \\
\text { Coscinodiscus argus } \\
\text { Coscinodiscus centralis } \\
\text { Coscinodiscus radiatus } \\
\text { Cyclotella litoralis } \\
\text { Proboscia alata } \\
\text { Shionodiscus oestrupii var. venrickae } \\
\text { Stellarima stellaris } \\
\text { Thalassionema pseudonitzschioides } \\
\text { Thalassiosira binata } \\
\text { Thalassiosira conferta } \\
\text { Thalassiosira delicatula } \\
\text { Thalassiosira dyporocyclus } \\
\text { Thalassiosira elsayedii } \\
\text { Thalassiosira poro-irregulata } \\
\text { Thalassiosira rotula }\end{array}$ & $\begin{array}{l}\text { Romero and Armand (2010), Romero } \\
\text { and Fischer (2017), Crosta et al. (2012), } \\
\text { Romero et al. (2009, 2012, 2020) }\end{array}$ \\
\hline
\end{tabular}

4. Open ocean Alveus marinus Aserolampra marylandica Asteromphalus arachne Asteromphalus cleveanus Asteromphalus flabellatus Asteromphalus heptactis Asteromphalus sarcophagus Azpeitia africana Azpeitia neocrenulata Azpeitia nodulifera Azpeitia tabularis Bacteriastrum elongatum Bogorovia spp.

Coscinodiscus reniformis 
Table 3. Continued.

\begin{tabular}{|c|c|c|c|}
\hline & Group & Species & Main References \\
\hline 4. & Open ocean & $\begin{array}{l}\text { Detonula pumila } \\
\text { Fragilariopsis doliolus } \\
\text { Guinardia cylindrus } \\
\text { Haslea } \text { spp. } \\
\text { Hemidiscus cuneiformis } \\
\text { Leptocylindrus mediterraneus } \\
\text { Nitzschia aequatoriale } \\
\text { Nitzschia bicapitata } \\
\text { Nitzschia capuluspalae } \\
\text { Nitzschia interruptestriata } \\
\text { Nitzschia sicula } \\
\text { Nitzschia sicula var. rostrata } \\
\text { Planktoniella sol } \\
\text { Pseudo-nitzschia spp. } \\
\text { Pseudosolenia calcar-avis } \\
\text { Pseudotriceratium punctatum } \\
\text { Rhizosolenia acuminata } \\
\text { Rhizosolenia bergonii } \\
\text { Rhizosolenia imbricatae } \\
\text { Rhizosolenia robusta } \\
\text { Rhizosolenia setigera } \\
\text { Rhizosolenia styliformis } \\
\text { Roperia tessellata } \\
\text { Shionodiscus oestrupii var. oestrupii } \\
\text { Thalassionema bacillare } \\
\text { Thalassionema frauenfeldii } \\
\text { Thalassionema nitzschioides var. capitulata } \\
\text { Thalassionema nitzschioides var. inflata } \\
\text { Thalassionema nitzschioides var. lanceolata } \\
\text { Thalassionema nitzschioides var. parva } \\
\text { Thalassiosira eccentrica } \\
\text { Thalassiosira endoseriata } \\
\text { Thalassiosira ferelineata } \\
\text { Thalassiosira lentiginosa } \\
\text { Thalassiosira leptopus } \\
\text { Thalassiosira lineata } \\
\text { Thalassiosira nanolineata } \\
\text { Thalassiosira parthenia } \\
\text { Thalassiosira plicata } \\
\text { Thalassiosira punctigera } \\
\text { Thalassiosira sacketii var. sacketii } \\
\text { Thalassiosira sacketii var. plana } \\
\text { Thalassiosira subtilis } \\
\text { Thalassiosira symmetrica } \\
\text { Thalassiothrix spp. }\end{array}$ & $\begin{array}{l}\text { Romero and Armand (2010), Romero } \\
\text { and Fischer (2017), Romero } \\
\text { et al. (2005, 2020), Crosta et al. (2012) }\end{array}$ \\
\hline
\end{tabular}

mostly above $50 \%$ almost throughout until the end of the trap experiment in June 2009 (Fig. 2b). The dominance of benthic diatoms at CBmeso also prevails after 2009 (Romero, unpubl. data). The marked increase in variability of the benthic relative contribution is clearly evidenced by the highest variability among all diatom groups (1 SD of each group for the whole study interval is (1) benthic $= \pm 23.68 \%$, (2) coastal upwelling $= \pm 10.46 \%$, (3) coastal planktonic $= \pm 11.88 \%$, and (4) open ocean $= \pm 16.00 \%$ ).

The impact of the environmental variables on diatom communities was investigated by comparing the sample clustering and the values of low-frequency forcings (Fig. 4). AMO, the Shannon diversity index, and total diatom flux show significant differences between groups (Kruskal-Wallis test; $p$ value $<0.05)$, whereas no statistical differences have been 

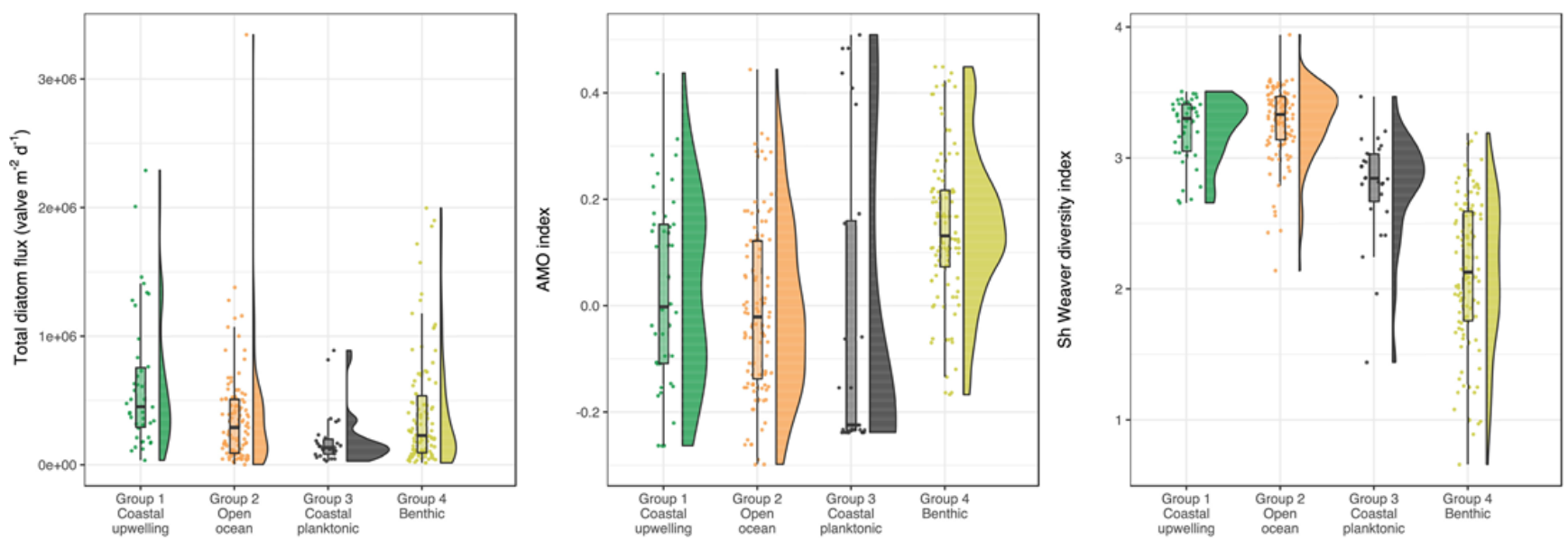

Figure 4. Comparison of clusters extracted from multivariate analysis according to total diatom flux, AMO, and Shannon diversity measured.

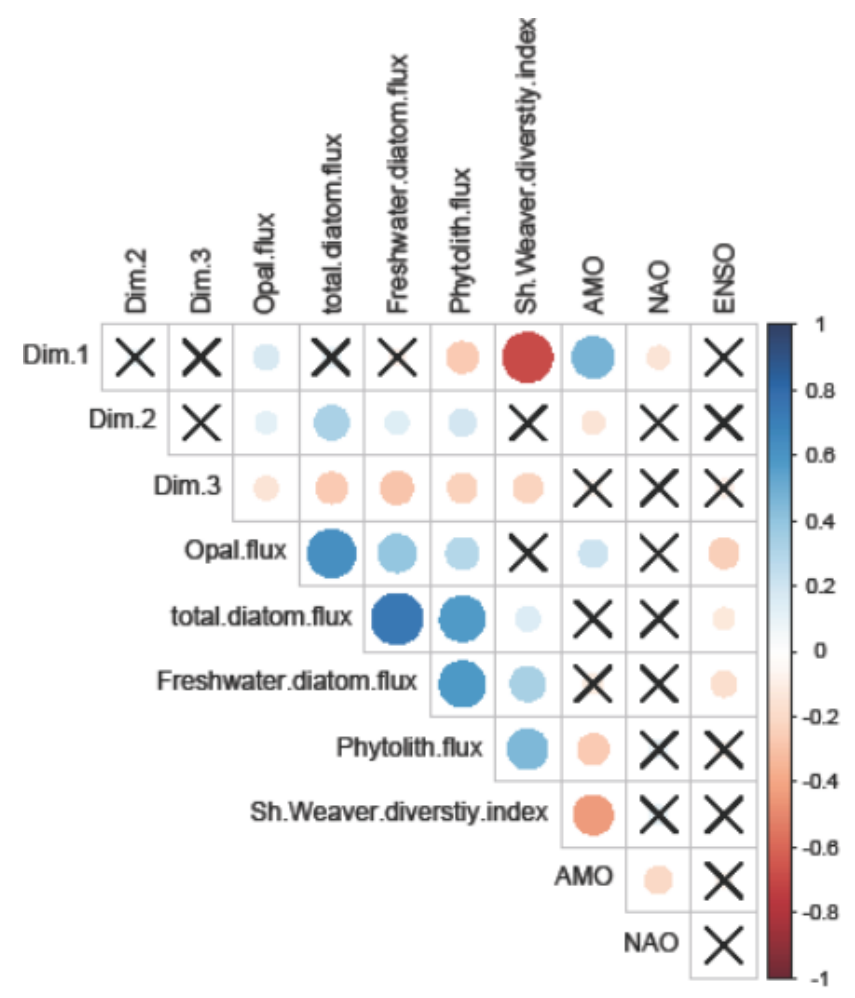

Figure 5. Correlogram representing Spearman's correlation rank between CA axes (i.e., Dim.1, Dim.2, Dim.3), environmental variables, and climatic and diversity indexes. Color scale and circle size indicate the strengths of the correlation. Squares without an " $X$ " indicate significant relationships ( $p$ value $<0.05$ ). For interpretation of the references to color in this figure legend, the reader is referred to the web version of this article. observed for the NAO, ENSO, and Pacific Decadal Oscillation indices. Only benthic diatoms (group 4) show higher AMO values compared to the three other groups (pairwise Wilcoxon rank sum test; $p$ value $<0.05$ ). In addition, a gradient in the Shannon diversity index of the diatom populations (Fig. 4c) is observed with predominantly low values (1.72.5) corresponding to benthic (group 4), intermediate values (2.7-3) for coastal planktonic (group 3), and high values (3.1-3.45) in samples dominated by coastal upwelling and open-ocean populations (groups 2 and 1) (pairwise Wilcoxon rank sum test; $p$ value $<0.05$ ). The statistical analysis also shows that, during intervals dominated by coastal upwelling populations, the total diatom flux was higher compared to values when other diatom groups dominated the community. The correlogram performed between CA axes and the lowfrequency climate indices also confirms these trends (Fig. 5). A significant positive and negative correlation was found between the first CA axis sample scores and AMO and Shannon diversity index (Fig. 3). Given that the first CA is positively driven by the benthic group, this confirms the outstanding dominance of the benthic diatom $D$. surirella after May 2002, which also appears to be linked to the strengthening of AMO. In the same way, the fact that the second CA axis is positively correlated with total diatom flux confirms that coastal upwelling diatoms deliver a large number of diatom valves.

\section{Discussion}

The long-term diatom record at the site CBmeso offers the possibility of discussing population dynamics in the context of the high-frequency atmospheric and hydrographic dynamics along the CC EBUE and the low-frequency climate variability in the North Atlantic. In Sect. 5.1, we discuss the impact of climate forcing on the long-term trends of the diatom community and the total diatom flux and the two-step shift 


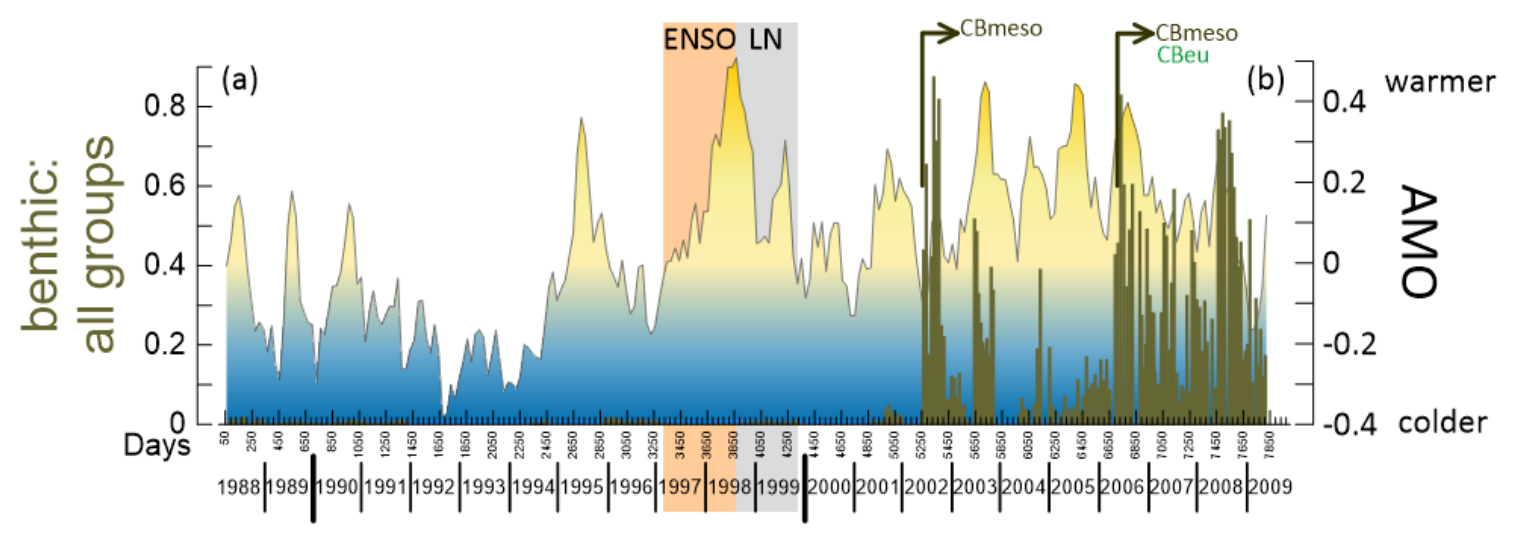

Figure 6. Time series of ratio benthic : all groups (olive bars, a) at the site CBmeso and the Atlantic Multidecadal Oscillation (AMO, b) between March 1988 and May 2009. The fill in (b) represents the colder phase (blue) and the warmer phase (yellow) of AMO. Inverted arrows in the lower panel below the benthic : all group bars represent the abrupt increase in relative contribution of benthic diatoms, first seen at CBmeso in early winter 2002 and in winter 2006 at CBmeso and at CBeu (Romero and Fischer, 2017; Romero et al., 2020). Shadings in the background: light orange, El Niño-Southern Oscillation (ENSO); grey, La Niña (LN). For interpretation of the references to color in this figure legend, the reader is referred to the web version of this article.

in the species-specific composition of diatom populations. In the second subsection (Sect. 5.2), we compare the CBmeso data with those previously published at the eutrophic site CBeu (Romero and Fischer, 2017; Romero et al., 2020) and discuss (i) the effect of the giant chlorophyll filament and (ii) the impact of lateral advection from the shallow coastal area off Mauritania upon the hemi- and pelagic realms along the NE Atlantic Ocean.

Based on outstanding shifts in the species-specific composition of the diatom assemblage that occurred throughout the study (Figs. 2b and 3), we propose three main intervals in the multiyear evolution of populations and discuss them in view of major environmental forcings: (i) early 1988-late 1996 (gradually decreasing trend of coastal upwelling diatoms), (ii) 1997-1999 (highest contribution of diatoms typical of low- to moderate-productivity waters), and (iii) 2002the middle of 2009 (major shift in the species-specific composition: extraordinary increase in and dominance of benthic diatoms).

\subsection{The impact of low-frequency forcing on the variability of diatom populations off Mauritania}

\subsubsection{AMO and the two-step increase in benthic diatoms' contribution}

Based on the long-term trends of our data and their statistical analysis (Figs. 2-5), we propose that the three intervals reflect the response of the diatom populations to the impact of low-frequency environmental forcing. As described above in Sect. 4.2, the benthic diatom community appears positively correlated with AMO (Fig. 6). Among low-frequency forcings affecting the subtropical North Atlantic (see above Sect. 3.2), the AMO plays a key role in determining decadal variations in SST and meridional circulation (e.g., Wang and
Zhang, 2013; Knight et al., 2005; McCarthy et al., 2015). It is widely accepted that AMO is largely induced by AMOC variations and the associated fluctuations of heat transport (Knight et al., 2005; Medhaug and Furevik, 2011; Wang and Zhang, 2013; McCarthy et al., 2015; details in Sect. 3.2.1). Using observational data and model experiments, Wang and Zhang (2013) concluded that the cooling of the subtropical North Atlantic (where the CBmeso is deployed) is largely due to the meridional advection by the anomalous northward current. The anomalous cooling appears below $100 \mathrm{~m}$ and extends down to ca. $1500 \mathrm{~m}$ water depth, with a maximum cooling around $200 \mathrm{~m}$ between 8 and $20^{\circ} \mathrm{N}$. During the cold phase of the AMO, the anomalous southward meridional current is responsible for the subsurface ocean warming (Wang and Zhang, 2013).

An additional effect of the AMO impact is the significant long-term weakening (strengthening) of the gyre during warm (cold) phase of AMO. This weakening contributes to the anomalous northward MC in subsurface waters (ca. 100$200 \mathrm{~m}$ ), while its strengthening causes an anomalous southward current. The decreasing contribution of upwelling diatoms between 1988 and 1996 (Figs. 2b and 3c) matches the transition from a predominantly cool into a warm AMO phase during the late 1990s (Fig. 6; Wang and Zhang, 2013, and references therein). The simultaneous increase in the contribution of open-ocean diatoms is additional evidence for decreased diatom productivity (Fig. 2) and the predominant occurrence of oligo-mesotrophic waters bathing the CBmeso site towards the earliest 1990 s, with the stronger input of the silica-depleted NACW (see Sect. 3.1).

In addition to AMO forcing, the possible impact of NAO on the seasonal dynamics of the biogenic silica (opal) fluxes and eolian input off Mauritania has been previously discussed in Fischer et al. (2016). They observed that winter 
biogenic silica fluxes had an increasing trend with an increasing NAO index (Fischer et al., 2016). However, our statistical approach (clustering and the Kruskal-Wallis tests) does not show any clear relationship between each individual diatom group and the NAO index. Nevertheless, the correlogram (Fig. 5) shows that the samples' scores of first CA axis (Dim. 1 , which discriminates the benthic diatoms from the other diatom groups) seem to be impacted by the NAO, but with a low percentage of variance explained (low $R^{2}$ ) compared to AMO. Interestingly, the correlogram also showed a reverse correlation between AMO and NAO (Fig. 5). These results match previous observations and modeling experiments and support the fact that the linkage between AMO and NAO is still debatable. An indication of some relation between NAO and AMO, with northerly winds associated with a positive AMO and zonal winds with a negative state of AMO, has been proposed (Yamamoto and Palmer, 2016). At this stage, we conclude that AMO seems to impact stronger on the multiyear pattern of variability of diatom communities off Mauritania than NAO and confirm a potential link between both climatic indexes.

An extraordinary feature of the multiyear dynamics of diatom populations at the CBmeso site is the sharp shift in the species contribution between May and June 2002 (Fig. 2b). The species shift leading to larger contribution of benthic diatoms follows a two-step increase pattern: the first abrupt increase is observed in late May-early June 2002. The second increase occurs in winter 2006, with values mostly above $50 \%$ almost until the end of the trap experiment (June 2009, Fig. 6). The dominance of benthic taxa also prevails throughout until recently recovered traps at the site CBmeso (Oscar E. Romero, unpublished data). As already observed in previous studies at the neritic site $\mathrm{CBeu}$ (Romero and Fischer, 2017; Romero et al., 2020; see further discussion in Sect. 5.2), the diatom D. surirella also dominates the benthic community at the site CBmeso. This small diatom (length $=5-15 \mu \mathrm{m}$ ) occurs predominantly attached to sand grains in shallow marine habitats within the euphotic zone and is an occasional component of the thycoplanktonic community (Andrews, 1981). Delphineis surirella originally thrives in shallow waters (above $50 \mathrm{~m}$ depth), overlying the wide Mauritanian upper shelf, and its valves are suspended and transported downslope until reaching the traps at the deep mesotrophic CBmeso site.

The intensification of the transport of AMOC intermediate waters during the warm phase of the AMO (Wang and Zhang, 2013) might have also contributed to the strengthening of lateral transport from subsurface shelf waters in the Mauritanian offshore region. Earlier time-series studies at the CBmeso site (Fischer et al., 2009, 2016) and observationbased model experiments conducted along the Mauritanian upwelling (Helmke et al., 2005; Karakaş et al., 2006; Nowald et al., 2015) already discussed the role of intermediate and deep nepheloid layers in the lateral transport of particles and microorganisms remains upon the pelagic realm. Based on the vigorous mixing in the uppermost water column due to the confluence of northward and southward water masses and strong, predominantly westward winds off Mauritania (Fig. 1; see Sect. 3.1), the offshore transport from shallow into deeper waters is most intense between 20.5 and $23.5^{\circ} \mathrm{N}$ along the northwestern African margin. Erosional processes in the very dynamic coastal realm significantly contribute to the downward transport of particulates and microorganism remains (Meunier et al., 2012) and are responsible for sporadic particle clouds advected up to several hundreds of kilometers offshore within intermediate and bottom nearnepheloid layers (Fischer and Karakaş, 2009; Fischer et al., 2009; Nowald et al., 2015). This nepheloid-layer-mediated transport additionally benefits from the bathymetry of the Mauritanian shelf and slope (Nowald et al., 2015). The subsurface layer (100 to $300 \mathrm{~m}$ water depth), in turn strongly affected by the AMOC intensification due to AMO impact (Wang and Zhang, 2013), might be the place of mixing processes of laterally advected materials from the shelf (where benthic diatoms predominantly thrive) by the activity of the giant chlorophyll filament, with relatively fresh material derived from the open-ocean surface (as represented by the other three diatom groups; Fig. 2). As the nepheloid-layermediated transport contributes more intensively to the deposition of diatom remains upon the lower slope and beyond than direct vertical settling from the euphotic layer does after 2001 , the area of final burial of diatom valves is effectively displaced from their production environment in surface waters overlying the CBmeso site into their area of final deposition in deep-sea sediments below $4000 \mathrm{~m}$ water depth.

\subsubsection{The occurrence of the strong 1997 ENSO and the response of the diatom community off Mauritania}

CB8 and CB9, the traps temporally corresponding to the 1997-1999 ENSO and La Niña, were deployed at different depths (Table 1; see also above Sect. 2.1). Although this depth difference might have impacted on the total diatom flux (stronger dissolution in deeper waters, Romero and Armand, 2010; larger catchment area of lower traps, Fischer et al., 2016), the total diatom flux is low in both traps and hardly shows any dramatic increase or decrease with depth (CB9, Fig. 2a). Additionally, the species-specific composition of the diatom community shows a significant match between traps CB8 and CB9 (Fig. 2b). The dominance of openocean and coastal planktonic diatoms - common in waters of moderate- to low-nutrient conditions - matches well with the occurrence of low total diatom flux. This evidences that no significant difference in the record of diatom fluxes between the upper and lower traps occurred despite different depth deployments.

The long-term trends mainly determined by the lowfrequency AMO (see Sect. 5.1.1) were altered in the second half of the 1990s by the impact of the strong 1997 ENSO (McPhaden, 1999). We postulate that both low coastal up- 
welling diatom values $(\leq 4 \%)$ and total diatom flux between February 1997 and November 1999 (Fig. 2) are the response of the diatom community off Mauritania to the impact of ENSO upon the low-latitude NE Atlantic. The dominance of taxa predominantly related to waters of low to moderate productivity (1997: highest contribution of open-ocean diatoms and lowest of coastal upwelling diatoms; 1998-1999: highest contribution of coastal planktonic and open-ocean diatoms, typical of oligo-mesotrophic waters) evidences considerable changes in the physical setting of the Mauritanian upwelling. Since the interval 1996-1999 records the lowest total diatom flux for the entire study (Fig. 2a, Table 2), we argue that ENSO negatively impacted on diatom productivity off Mauritania.

A positive ENSO goes along with the weakening of ENE winds off Mauritania (Pradhan et al., 2006; Fischer et al., 2016). Weakened E-NE trades lead to the deepening of the thermocline below the depth of the source of upwelled water, thus hindering the mixing of the water column and causing upwelling intensity off Mauritania to decrease until early 1998 (Pradhan et al., 2006). Additionally, the size of the Mauritanian chlorophyll filament decreased between winter 1997 and spring 1998, while becoming unusually large from autumn 1998 to spring 1999 (Fischer et al., 2009). Complementary support of this ENSO-mediated impact on surface water productivity off Mauritania is provided by variations in bulk biogenic fluxes at the CBmeso site. The almost 2.5 times higher organic carbon flux during 1998-1999 than in 1997 (Helmke et al., 2005) led to the proposal that, after weakening of wind intensity due to the impact of ENSO on the physical setting, upwelling intensified immediately afterward during La Niña (Fischer et al., 2016). Similarly, the seasonal cycle of surface chl $a$ distribution in waters above the CBmeso site reveals a noticeable event $(\sim 250 \%$ increase $)$ in Mauritanian coastal waters (Pradhan et al., 2006).

ENSO has a significant global impact on the dynamics of primary producers via teleconnections (McPhaden, 1999; Levine et al., 2017). Aperiodic, pronounced decreases in the total diatom flux matching the occurrence of strong ENSOs in other ocean basins have been previously associated with limiting nutrient levels due to ENSO-derived perturbations. The diatom production in hemipelagic waters in the Chilean EBUE decreased extraordinarily during the strong 1997 ENSO compared to earlier years (Romero et al., 2001). Similar negative impacts linked to ENSO teleconnections have been proposed for other ocean areas, including the southern Californian EBUE (Lange et al., 2000), the Cariaco Basin (Romero et al., 2009b), the western Mediterranean Sea (Bárcena et al., 2004; Rigual-Hernández et al., 2013), and the subarctic Pacific Ocean (Takahashi, 1987).

\subsection{Comparison of diatom fluxes and population dynamics within the giant Mauritanian chlorophyll filament (CBmeso vs. CBeu)}

In this subsection, we compare the total diatom flux and the assemblage composition at the site CBmeso with previous results from the nearby trap site CBeu gained between 2003 and 2009 (Romero and Fischer, 2017; Romero et al., 2020). The CBeu site locates ca. 80 nautical miles $(\sim 150 \mathrm{~km})$ offshore at the continental slope below the giant Mauritanian chlorophyll filament and hence between the coastline and the outer CBmeso site (Fig. 1). These two trap locations are under different nutrient availability and upwelling intensity (Romero and Fischer, 2017; Fischer et al., 2016, 2019).

The less favorable conditions for diatom productivity in waters overlying the site CBmeso (Fig. 1b-d) are evidenced by lower total diatom flux than at the site CBeu. In the seasonal pattern, the total diatom flux at the site CBmeso is always 2 orders of magnitude lower than values obtained at the site CBeu (Fig. 7a). This also happens during fall, when the highest average seasonal flux is recorded at CBmeso $\left(5.6 \times 10^{5}\right.$ valves per square meter per day vs. $3.3 \times 10^{6}$ valves per square meter per day). We hypothesize that these flux differences reflect (i) the more intense upwelling in waters overlying the Mauritanian slope (Mittelstaedt, 1983, 1991; Cropper et al., 2014), (ii) the weakening of the offshore transport via the chlorophyll filament (Fig. 1b), (iii) the seaward decreasing concentration of nutrients within the filament (Lathuilière et al., 2008; Meunier et al., 2012), and (iv) the offshore weakening of the lateral transport (Karakaş et al., 2006; Nowald et al., 2015). According to satellite imagery (Van Camp et al., 1991; Gabric et al., 1993; Fischer et al., 2016; Fig. 1b-d), the CBmeso mooring locates only occasionally beneath the giant chlorophyll filament. In general, the larger DSi availability (approximately $10 \mathrm{vs.} 5 \mu \mathrm{M}$ ) and the higher $\mathrm{Si}: \mathrm{N}$ ratios of the source waters (SACW vs. $\mathrm{NACW}=0.6 \mathrm{vs}$. 0.3; Arístegui et al., 2009) in coastal water bathing site CBeu are reflected in ca. 3-fold-higher biogenic silica fluxes at the coastal CBeu - whose particle downward transport is additionally affected by strong ballasting due to higher lithogenic input from the nearby western African continent - compared to the offshore CBmeso site (Fischer et al., 2019).

Complementary support of the scenario of lower (higher) productivity levels at $\mathrm{CBmeso}(\mathrm{CBeu})$ is provided by the species-specific composition of the assemblage: relative contribution of groups related with oligo-mesotrophic waters is higher at $\mathrm{CBmeso}$ than at $\mathrm{CBeu}$ (coastal planktonic and open ocean, Fig. 7d and e), while the opposite is true for diatoms typical of eutrophic waters (Fig. 7c). Despite the difference in the relative contribution, the species-specific composition of diatom groups is remarkably similar at both sites. All the main taxa of diatom groups at the site CBmeso (Table 3; see also Sect. 4.2) are also found in CBeu samples (see Table 2 in Romero and Fischer, 2017). Both trap sites are linked via lat- 
(a) Total diatom flux

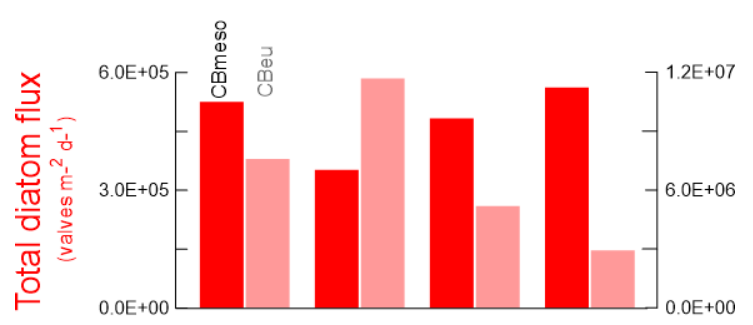

(b) Benthic

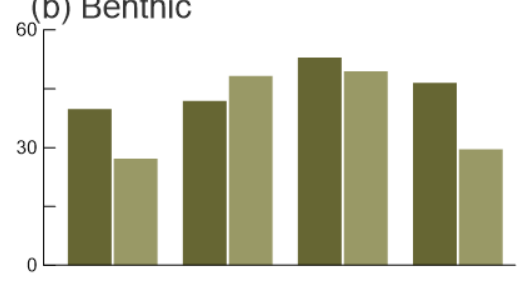

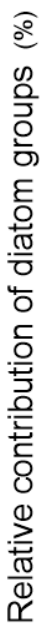

(c) Coastal upwelling

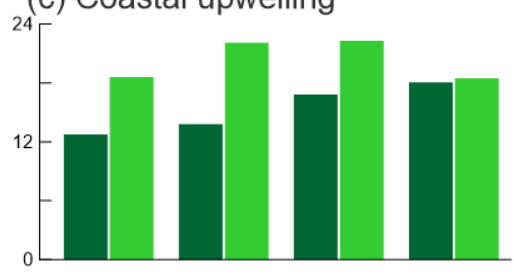

(d) Coastal planktonic

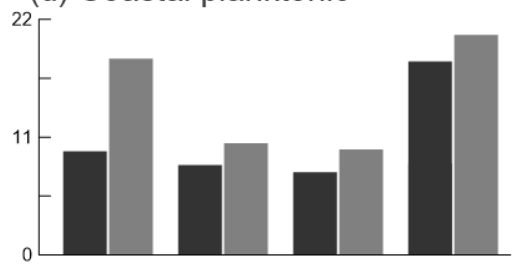

(e) Open-ocean

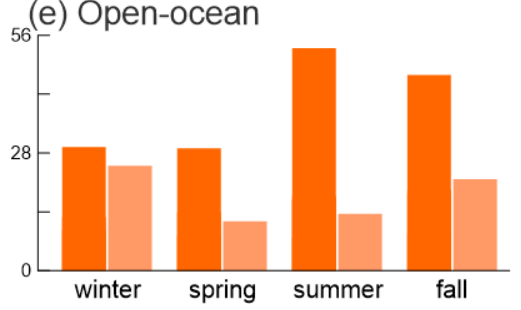

Figure 7. Comparison of seasonal values of (a) total diatom flux (valves per square meter per day) and (b-e) the relative contribution of diatom groups (\%) at the sites CBmeso and CBeu (see Sect. 2.1 for trap locations). Darker colors represent flux and relative percentage at CBmeso, while lighter colors show those of CBeu. Note that the right $y$ axis for (a) total diatom flux corresponds to $\mathrm{CBeu}$, and the left-hand $y$ axis corresponds to the CBmeso site. For the speciesspecific composition of each group at CBmeso, see Sect. 4.2. and Table 2. The species-specific composition of groups at CBeu was originally published in Romero and Fischer (2017). Colors used for identifying each diatom group are the same as in Fig. 2b. For interpretation of the references to color in this figure legend, the reader is referred to the web version of this article. eral advection through near-surface, intermediate, and deeper nepheloid layers (Fischer et al., 2016).

In their earlier study, Romero and Fischer (2017) observed that the shift in the species composition at the site CBeu toward a benthic-dominated assemblage occurred in early winter 2006. Since benthic diatoms in the deeper CBmeso traps are transported via nepheloid layers from shallow coastal waters (see Sect. 5.1.1), the high percentage of benthic species at the CBmeso site (Fig. 7b) evidences the impact of particulates derived from the Mauritanian inner shallow shelf (Romero and Fischer, 2017; Fischer et al., 2009, 2016, 2019; Romero et al., 2020). The simultaneous occurrence of the second increase in benthic diatoms at CBmeso and the increase at the neritic site CBeu (Fig. 7) is a striking feature of the population shift over a large part of the Mauritanian upwelling system. Phytoplankton thriving in Mauritanian surface waters can be transported as far as $400 \mathrm{~km}$ offshore from coastal waters (Gabric et al., 1993; Helmke et al., 2005; Barton et al., 2013). The transport of particulates and microorganism remains from their source in shallow coastal waters into the hemipelagic realm probably occurs within weeks (Karakaş et al., 2006, 2009). The MC might have helped in detaching benthic diatoms from their substrata (Romero and Fischer, 2017) and in transporting them northwestward into the hemipelagic realm (where the CBmeso traps of this study were deployed). These observations offer additional evidence of the impact of AMO via the strengthening of the meridional advection, the major nutrient input via the MC, and the nepheloid-layer-mediated transport into the deeper Mauritanian waters.

\section{Conclusions}

This multiyear study of diatom populations' dynamics offers an overall picture of the long-term evolution of diatom-based productivity and fluxes and the response of the community to the interaction of high- and low-frequency hydrographic and atmospheric forcing in the mid-latitude northeastern Atlantic Ocean. A unique, persistent trend in the long-term evolution of the total diatom flux, either decreasing or increasing, is not recognized in our ca. 20-year record.

The statistical analysis supports the proposed scenario of AMO as an important driver of diatom populations' dynamics off Mauritania. The occurrence of cold (1988-1996) and warm AMO phases (2001-2009) is reflected by a major shift in species-specific composition. This overall trend is interrupted by the impact of the strong 1997 ENSO. Changes in the physical setting following the 1997 ENSO (weakening of E-NE trade winds, thermocline deepening, weakened water column mixing) negatively affected diatom production off Mauritania. Less evident is a possible impact of NAO.

Our CBmeso trap results allow corroboration that the abrupt shift in the assemblage composition occurred earlier off Mauritania (starting May 2002) than previously demon- 
strated (Romero and Fischer, 2017; Romero et al., 2020) and followed two steps. The two-step increase in benthic diatoms' contribution at the CBmeso site suggests that the intensification of the slope and shelf poleward undercurrents into the hemipelagic environment appears linked to the warm phase of AMO and the associated AMOC changes.

Diatom remains sink not only vertically off Mauritania, but they are also laterally advected from the shelf to the deeper waters via the nepheloid-layer-mediated transport. Transported valves (siliceous remains) from shallow coastal into deeper waters beyond the slope should be considered for the calculation and model experiments of nutrient budgets (especially $\mathrm{Si}$ ) and the paleoenvironmental signal preserved in downcore sediments.

Understanding the degree of interannual to decadal variability in the Mauritania upwelling system is key for the prediction of future changes of primary productivity along the NW African margin as well in other economically important EBUEs. Our 1988-2009 data set might be instrumental in distinguishing between climate-forced and intrinsic variability of populations of primary producers (e.g., diatoms) and is especially important for establishing the scientific basis for forecasting and modeling future states of this ecosystem and its decadal changes.

Data availability. Data are available at https://doi.org/10.1594/PANGAEA.922784 (Romero, 2020).

Author contributions. OER and GF devised the study. OER collected the data and wrote the manuscript. SR performed the statistical analysis. All authors contributed to interpretation and discussion of results.

Competing interests. The authors declare that they have no conflict of interest.

Acknowledgements. We are greatly indebted to the captains and crews of the RVs Meteor, Maria S. Merian, Polarstern, and Poseidon for several research expeditions off Mauritania. Much appreciated is the help of the RV Poseidon headquarters at Geomar (Klas Lackschewitz, Kiel, Germany) during the planning phases of these research expeditions and the support from the German, Moroccan, and Mauritanian authorities. The Institut Mauretanien de Recherches Océanographiques et des Pêches at Nouadhibou (Mauritania) is acknowledged for its support and help in getting the necessary permissions to perform our multiyear trap experiments in Mauritanian coastal waters. Götz Ruhland, Nico Nowald, and Marco Klann (MARUM, Bremen) were responsible for the mooring deployments and home lab work. The long-term funding by the German Research Foundation (DFG) through SFB 261, the Research Center Ocean Margins (RCOM), and the current MARUM Excellence Cluster "The Ocean in the Earth System" (University of Bremen, Bremen, Germany) made this study possible. Reviews and suggestions by Andres Rigual-Hernandez and the anonymous referee and $B G$ associate editor Ny Riavo G. Voarintsoa greatly improved this paper and are thankfully acknowledged.

Financial support. The article processing charges for this openaccess publication were covered by the University of Bremen.

Review statement. This paper was edited by Ny Riavo G. Voarintsoa and reviewed by Andres Rigual-Hernandez and one anonymous referee.

\section{References}

Abrantes, F., Meggers, H., Nave, S., Bollman, J., Palma, S., Sprengel, C., Henderiks, J., Spies, A., Salgueiro, E., Moita, T., and Neuer, S.: Fluxes of micro-organisms along a productivity gradient in the Canary Islands region $\left(29^{\circ} \mathrm{N}\right)$ : implications for paleoreconstructions, Deep-Sea Res. Pt. II, 49, 3599-3629, 2002.

Andrews, G. W.: Revision of the diatom genus Delphineis and morphology of Delphineis surirella (Ehrenberg) G. W. Andrews, n. comb, edited by: Ross, R., Proc. Sixth Diatom Symp., Otto Koeltz, Koenigstein, 81-92, 1981.

Arístegui, J., Barton, E. C., Aillvarez-Salgado, X. A., Santos, A. M. P., Figueiras, F. G., Kifani, S., HernaìndezLeoìn, S., Mason, E., Machuì, E., and Demarcq, H.: Sub-regional ecosystem variability in the Canary Current upwelling, Prog. Oceanogr., 83, 33-48, https://doi.org/10.1016/j.pocean.2009.07.031, 2009.

Bakun, A.: Global climate change and intensification of coastal ocean upwelling, Science, 247, 198-201, 1990.

Bakun, A., Field, D. B., Redondo-Rodriguez, A., and Weeks, S. J.: Greenhouse gas, upwelling-favorable winds, and the future of coastal ocean upwelling ecosystems, Global Change Biol., 16, 1213-1228, 2010.

Bárcena, M. A., Flores, J. A., Sierro, F. J., Pérez-Folgado, M., Fabres, J., Calafat, A., and Canals, M: Planktonic response to main oceanographic changes in the Alboran Sea (Western Mediterranean) as documented in sediment traps and surface sediments, Mar. Micropalaleontol., 53, 423-445, 2004.

Barton, E. D., Field, D. B., and Roy, C.: Canary current upwelling: More or less?, Prog. Oceanogr., 116, 167-178, 2013.

Behrenfeld, M. J., Randerson, J. T., McClain, C. R., Feldman, G. C., Los, S. O., Tucker, C. J., Falkowski, P. G., Field, C. B., Frouin, R., Esaias, W. E., Kolber, D. D., and Pollack, N. H.: Biospheric Primary Production During an ENSO Transition, Science, 291, 2594-2597, 2001.

Buckley, M. W. and Marshall, J.: Observations, inferences, and mechanisms of Atlantic Meridional Overturning Circulation variability, Rev. Geophys., 54, 5-63, https://doi.org/10.1002/2015RG000493, 2016.

Buesseler, K. O., Antia, A. A., Chen, M., Fowler, S. W., Gardner, W. D., Gustafsson, O., Harada, K., Michaels, A. F., Rutgers van der Loeff, M., Sarin, M., Steinberg, D. K., and Trull, T.: An assessment of the use of sediment traps for estimating upper ocean particle fluxes, J. Mar. Res., 65, 345-416, 2007. 
Chavez, F. P. and Messié, M.: A comparison of Eastern Boundary Upwelling Ecosystems, Prog. Oceanogr., 83, 80-96, 2009.

Clement, A., Bellomo, K., Murphy, L. N., Cane, M. A., Mauritsen, T., Rädel, G., and Stevens, B.: The Atlantic Multidecadal Oscillation without a role for ocean circulation, Science, 350, 320-324, https://doi.org/10.1126/science.aab3980, 2015.

Cropper, T. E., Hanna, E., and Bigg, G. R.: Spatial and temporal seasonal trends in coastal upwelling off Northwest Africa, 19812012, Deep-Sea Res. Pt. I, 86, 94-111, 2014.

Crosta, X., Romero, O. E., Ther, O., and Schneider, R. R.: Climatically-controlled siliceous productivity in the eastern Gulf of Guinea during the last 40000 yr, Clim. Past, 8, 415-431, https://doi.org/10.5194/cp-8-415-2012, 2012.

Dong, B., Sutton, R. T., and Scaife, A. A.: Multidecadal modulation of El Niño-Southern Oscillation (ENSO) variance by Atlantic Ocean sea surface temperatures, Geophys. Res. Lett., 33, L08705, https://doi.org/10.1029/2006GL025766, 2006.

Enfield, D. B., Mestas-Nuñez, A. M., and Trimble, P. J.: The Atlantic Multidecadal Oscillation and its relation to rainfall and river flows in the continental U. S., Geophys. Res. Lett., 28, 2077-2080, 2001.

Fischer, G. and Karakaş, G.: Sinking rates and ballast composition of particles in the Atlantic Ocean: implications for the organic carbon fluxes to the deep ocean, Biogeosciences, 6, 85102, https://doi.org/10.5194/bg-6-85-2009, 2009.

Fischer, G., Krause, S. G., Neuer, S., and Wefer, G.: Shortterm sedimentation pulses recorded with a chlorophyll sensor and sediment traps in $900 \mathrm{~m}$ water depth in the Canary Basin, Limnol. Oceanogr., 41, 1354-1359, https://doi.org/10.4319/lo.1996.41.6.1354, 1996.

Fischer, G., Reuter, C., Karakaş, G., Nowald, N., and Wefer, G.: Offshore advection of particles within the Cape Blanc filament, Mauritania: Results from observational and modelling studies, Prog. Oceanogr., 83, 322-330, 2009.

Fischer, G., Romero, O., Merkel, U., Donner, B., Iversen, M., Nowald, N., Ratmeyer, V., Ruhland, G., Klann, M., and Wefer, G.: Deep ocean mass fluxes in the coastal upwelling off Mauritania from 1988 to 2012: variability on seasonal to decadal timescales, Biogeosciences, 13, 3071-3090, https://doi.org/10.5194/bg-13-3071-2016, 2016.

Fischer, G., Romero, O. E., Toby, E., Iversen, M., Donner, B., Mollenhauer, G., Nowald, N., Ruhland, G., Klann, M., Hamady, B., and Wefer, G.: Changes in the Dust-Influenced Biological Carbon Pump in the Canary Current System: Implications from a Coastal and an Offshore Sediment Trap Record Off Cape Blanc, Mauritania, Global Biogeochem. Cy., 33, 1100-1128, 2019.

Fréon, P., Barange, M., and Arístegui, J.: Eastern Boundary Upwelling Ecosystems: Integrative and comparative approaches, Prog. Oceanogr., 83, 1-14, https://doi.org/10.1016/j.pocean.2009.08.001, 2009.

Friese, C. A., van Hateren, J. A., Vogt, C., Fischer, G., and Stuut, J.B. W.: Seasonal provenance changes in present-day Saharan dust collected in and off Mauritania, Atmos. Chem. Phys., 17, 1016310193, https://doi.org/10.5194/acp-17-10163-2017, 2017.

Gabric, A. J., Garcia, L., Van Camp, L., Nykjaer, L., Eifler, W., and Schrimpf, W.: Offshore export of shelf production in the Cape Blanc (Mauritania) giant filament as derived from Coastal Zone Color Scanner Imagery, J. Geophys. Res., 98, 4697-4712, 1993.
Gómez-Gesteira, M., De Castro, M., Álvarez, I., Lorenzo, M. N., Gesteira, J. L. G., and Crespo, A. J. C.: Spatio-temporal Upwelling Trends along the Canary Upwelling System (1967-2006), Ann. NY. Acad. Sci., 1146, 320-337, https://doi.org/10.1196/annals.1446.004, 2008.

Hagen, E.: Northwest African upwelling scenario, Oceanol. Acta, 24, S113-S128, 2001.

Hasle, G. A. and Syvertsen, E. E.: Marine diatoms, in: Identifying marine diatoms and dinoflagellates, edited by: Thomas, C., Academic Press, Inc., San Diego, CA, 1-385, 1996.

Helmke, P., Romero, O. E., and Fischer, G.: Northwest African upwelling and its effect on off-shore organic carbon export to the deep sea, Global Biogeochem. Cy., 19, GB4015, https://doi.org/10.1029/2004GB002265, 2005.

Hurrell, J. W.: Decadal Trends in the North Atlantic Oscillation, Science, 269, 676-679, https://doi.org/10.1126/science.269.5224.676, 1995.

Jungclaus, J. H., Haak, H., Latif, M., and Mikolajewicz, U.: ArcticNorth Atlantic interactions and multidecadal variability of the meridional overturning circulation, J. Climate, 18, 4013-4031, 2005.

Karakaş, G., Nowald, N., Blaas, M., Marchesiello, P., Frickenhaus, S., and Schlitzer, R.: High-resolution modeling of sediment erosion and particle transport across the northwest African shelf, J. Geophys. Res., 111, C06025, https://doi.org/10.1029/2005JC003296, 2006.

Karakaş, G., Nowald, N., Schäfer-Neth, C., Iversen, M., Barkmann, W., Fischer, G., Marchesiello, P., and Schlitzer, R.: Impact of particle aggregation on vertical fluxes of organic matter, Prog. Oceanogr., 83, 331-341, 2009.

Knight, J. R., Allan, R. J., Folland, C. K., Vellinga, M., and Mann, M. E.: A signature of persistent natural thermohaline circulation cycles in observed climate, Geophys. Res. Lett., 32, L20708, https://doi.org/10.1029/2005GL024233, 2005.

Kremling, K., Lentz, U., Zeitzschell, B., Schulz-Bull, D. E., and Duinker, J. C.: New type of time-series sediment trap for the reliable collection of inorganic and organic trace chemical substances, Rev. Sci. Instrum., 67, 4360-4363, 1996.

Lange, C. B., Romero, O. E., Wefer, G., and Gabric, A. J.: Offshore influence of coastal upwelling off Mauretania, NW Africa, as recorded by diatoms in sediment traps at $2195 \mathrm{~m}$ water depth, Deep-Sea Res. Pt. I, 45, 985-1013, 1998.

Lange, C. B., Weinheimer, A. L., Reid, F. M. H., Tappa, E., and Thunell, R. C.: Response of siliceous microplankton from the Santa Barbara Basin to the 1997-98 El Niño Event, Cal. Coop. Ocean. Fish, 41, 186-193, 2000.

Lathuilière, C., Echevin, V., and Levy, M.: Seasonal and intraseasonal surface chlorophyll-a variability along the northwest African coast, J. Geophys. Res.-Oceans, 13, C05007, https://doi.org/10.1029/2007JC004433, 2008.

Legendre, P. and Legendre, L. F.: Numerical ecology, Developments in Environmental Modelling, Vol. 24, Elsevier, Amsterdam, 2012.

Levine, A. F. Z., McPhaden, M. J., and Frierson, D. M. W.: The impact of the AMO on multidecadal ENSO variability, Geophys. Res. Lett., 44, 3877-3886, 2017.

McCarthy, G. D., Smeed, D. A., Johns, W. E., Frajka-Williams, E., Moat, B. I., Rayner, D., Baringer, M. O., Meinen, C. S., Collins, J., and Bryden, H. J., Measuring the Atlantic Meridional 
Overturning Circulation at $26^{\circ} \mathrm{N}$, Prog. Oceanogr., 130, 91-111, https://doi.org/10.1016/j.pocean.2014.10.006, 2015.

McPhaden, M. J.: Genesis and Evolution of the 1997-98 El Niño, Science, 283, 950-954, 1999.

Medhaug, I. and Furevik, T.: North Atlantic 20th century multidecadal variability in coupled climate models: sea surface temperature and ocean overturning circulation, Ocean Sci., 7, 389404, https://doi.org/10.5194/os-7-389-2011, 2011.

Meunier, T., Barton, E. D., Barreiro, B., and Torres, R.: Upwelling filaments off Cape Blanc: interaction of the NW African upwelling current and the Cape Verde frontal zone eddy field?, J. Geophys. Res.-Oceans, 117, C08031, https://doi.org/10.1029/2012JC007905, 2012.

Mittelstaedt, E.: The upwelling area off Northwest Africa - a description of phenomena related to coastal upwelling, Prog. Oceanogr., 12, 307-331, 1983.

Mittelstaedt, E.: The ocean boundary along the northwest African coast: Circulation and oceanographic properties at the sea surface, Prog. Oceanogr., 26, 307-355, 1991.

Narayan, N., Paul, A., Mulitza, S., and Schulz, M.: Trends in coastal upwelling intensity during the late 20th century, Ocean Sci., 6, 815-823, https://doi.org/10.5194/os-6-815-2010, 2010.

Nave, S., Freitas, P., and Abrantes, F.: Coastal upwelling in the Canary Island region: spatial variability reflected by the surface sediment diatom record, Mar. Micropaleontol., 42, 1-23, 2001.

Nowald, N., Iversen, M. H., Fischer, G., Ratmeyer, V., and Wefer, G.: Time series of in-situ particle properties and sediment trap fluxes in the coastal upwelling filament off Cape Blanc, Mauritania, Prog. Oceanogr., 137, 1-11, 2015.

Nykjær, L. and Van Camp, L.: Seasonal and interannual variability of the coastal upwelling along northwest Africa and Portugal from 1981 to 1991, J. Geophys. Res., 99, 14197-14207, 1994.

O'Reilly, C. H., Huber, L. M., Woollings, T., and Zanna, L.: The signature of low-frequency oceanic forcing in the Atlantic Multidecadal Oscillation, Geophys. Res. Lett., 43, 2810-2818, https://doi.org/10.1002/2016GL067925, 2016.

Pardo, P., Padín, X., Gilcoto, M., Farina-Busto, L., and Pèrez, F.: Evolution of upwelling systems coupled to the long term variability in sea surface temperature and Ekman transport, Clim. Res., 48, 231-246, 2011.

Patti, B., Guisande, C. Riveiro, I., Thejll, P., Cuttitta, A., Bonanno, A., Basilone, G., Buscaino, G., and Mazzola, S.: Effect of atmospheric $\mathrm{CO}_{2}$ and solar activity on wind regime and water column stability in the major global upwelling areas, Estuar. Coast. Shelf S., 88, 45-52, https://doi.org/10.1016/j.ecss.2010.03.004, 2010.

Pelegrí, J. L., Marrero-Díaz, A., and Ratsimandresy, A. W.: Nutrient irrigation of the North Atlantic, Prog. Oceanogr., 70, 366-406, 2006.

Pelegrí, J. L., Peña-Izquierdo, J., Machín, F., Meiners, C., and Presas-Navarro, C.: Oceanography of the Cape Verde Basin and Mauritanian Slope Waters, in: Deep-Sea Ecosystems Off Mauritania, edited by: Ramos, A., Ramil, F., and Sanz, J., Springer, Dordrecht, 119-153, https://doi.org/10.1007/978-94-024-10235_3, 2017.

Pradhan, Y., Lavender, S. J., Hardman-Mountford, N. J., and Aiken, J.: Seasonal and inter-annual variability of chlorophylla concentration in the Mauritanian upwelling: Observation of an anomalous event during 1998-199, Deep-Sea Res. Pt. I, 53, 1548-1559, 2006.

Ragueneau, O., Tréguer, P., Leynaert, A., Anderson, R. F., Brzezinski, M. A., DeMaster, D. J., Dugdale, R. C., Dymond, J., Fischer, G., François, R., Heinze, C., Maier-Reimer, E., MartinJézéquel, V., Nelson, D. M., and Quéguiner, B.: A review of the Si cycle in the modern ocean: recent progress and missing gaps in the application of biogenic opal as a paleoproductivity proxy, Global Planet. Change, 26, 317-365, 2000.

Rigual-Hernández, A. S., Bárcena, M. A., Jordan, R. W., Sierro, F. J., Flores, J. A., Meier, K. J. S., Beaufort, L., and Heussner, S.: Diatom fluxes in the NW Mediterranean: evidence from a 12-year sediment trap record and surficial sediments, J. Plankton Res., 35, 1109-1125, 2013.

Rines, J. E. B. and Hargraves, P. E.: The Chaetoceros Ehrenberg (Bacillariophyceae) Flora of Narrangansett Bay, Rhode Island, U.S.A., 79, Bibl. Diatomol., J. Cramer, Berlin, Stuttgart, 196 pp., 1988.

Romero, O. E.: Total flux of diatoms and relative composition of diatom groups in trap samples at the CBmeso (=Cape Blanc mesotrophic), off Mauritania, PANGAEA, https://doi.org/10.1594/PANGAEA.922784, 2020.

Romero, O. E. and Armand, L. K.: Marine diatoms as indicators of modern changes in oceanographic conditions, in: The Diatoms, Applications for the Environmental and Earth Sciences, 2nd Edn., edited by: Smol, J. P. and Stoermer, E. F., Cambridge University Press, Cambridge, 373-400, 2010.

Romero, O. E. and Fischer, G.: Shift in the species composition of the diatom community in the eutrophic Mauritanian coastal upwelling: Results from a multi-year sediment trap experiment (2003-2010), Prog. Oceanogr., 159, 31-44, 2017.

Romero, O. E., Lange, C. B., Fischer, G., Treppke, U. F., and Wefer, G.: Variability in export production documented by downward fluxes and species composition of marine planktonic diatoms: Observations from the tropical and equatorial Atlantic, in: The Use of Proxies in Paleoceanography - Examples from the South Atlantic, edited by: Fischer, G. and Wefer, G., Springer Verlag, Berlin, Heidelberg, 365-392, 1999a.

Romero, O. E., Lange, C. B., Swap, R. J., and Wefer, G.: Eoliantransported freshwater diatoms and phytoliths across the equatorial Atlantic record temporal changes in Saharan dust transport patterns, J. Geophys. Res., 104, 3211-3222, 1999 b.

Romero, O. E., Hebbeln, D., and Wefer, G.: Temporal and spatial distribution in export production in the SE Pacific Ocean: evidence from siliceous plankton fluxes and surface sediment assemblages, Deep-Sea Res. Pt. I, 48, 2673-2697, 2001.

Romero, O. E., Lange, C. B., and Wefer, G.: Interannual variability (1988-1991) of siliceous phytoplankton fluxes off northwest Africa, J. Plankton. Res. 24, 1035-1046, https://doi.org/10.1093/plankt/24.10.1035, 2002.

Romero, O. E., Dupont, L., Wyputta, U., Jahns, S., and Wefer, G.: Temporal variability of fluxes of eolian-transported freshwater diatoms, phytoliths, and pollen grains off Cape Blanc as reflection of land-atmosphere-ocean interactions in northwest Africa, J. Geophys. Res., 108, 3153, https://doi.org/10.1029/2000JC000375, 2003.

Romero, O. E., Armand, L. K., Crosta, X., and Pichon, J.-J.: The biogeography of major diatom taxa in Southern Ocean sur- 
face sediments: 3. Tropical/Subtropical species, Palaeogeogr. Palaeocl., 223, 49-65, 2005.

Romero, O. E., Rixen, T., and Herunadi, B.: Effects of hydrographic and climatic forcing on diatom production and export in the tropical southeastern Indian Ocean, Mar. Ecol. Progr. Ser., 384, 6982, https://doi.org/10.3354/meps08013, 2009a.

Romero, O. E., Thunell, R. C., Astor, Y., and Varela, R.: Seasonal and interannual dynamics in diatom production in the Cariaco Basin, Venezuela, Deep-Sea Res. Pt. I, 56, 571-581, https://doi.org/10.1016/j.dsr.2008.12.005, 2009b.

Romero, O. E., Baumann, K.-H., Zonneveld, K. A. F., Donner, B., Hefter, J., Hamady, B., Pospelova, V., and Fischer, G.: Flux variability of phyto- and zooplankton communities in the Mauritanian coastal upwelling between 2003 and 2008, Biogeosciences, 17, 187-214, https://doi.org/10.5194/bg-17-187-2020, 2020.

Round, F. E., Crawford, R. M., and Mann, D. G.: The diatoms, Cambridge University Press, Cambridge, 747 pp., 1990.

Sancetta, C. and Calvert, S. E.: The annual cycle of sedimentation in Saanich Inlet, British Columbia: implications for the interpretation of diatom fossil assemblages, Deep-Sea Res., 35, 71-90, 1988.

Schrader, H.-J. and Gersonde, R.: Diatoms and silicoflagellates, in: Micropaleontological counting methods and techniques - an exercise on an eight meter section of the Lower Pliocene of Capo Rosello, Sicily, edited by: Zachariasse, W. J., Riedel, W. R., Sanfilippo, A., Schmidt, R. R., Brolsma, M. J., Schrader, H., Gersonde, R., Drooger, M. M., and Broekman, J. A., Utrecht Micropaleontological Bulletin, Utrecht, 17, 129-176, 1978.

Stevenson, S., Fox-Kemper, B., Jochum, M., Neale, R., Deser, C., and Meehl, G., Will there be a significant change to El Niño in the twenty-first century?, J. Climate, 25, 2129-2145, 2012.
Takahashi, K.: Response of subarctic Pacific diatom fluxes to the 1982-1983 El Niño disturbance, J. Geophys. Res, 93, 387-392, 1987.

Van Camp, L., Nykjær, L., Mittelstaedt, E., and Schlittenhardt, P.: Upwelling and boundary circulation off Northwest Africa as depicted by infrared and visible satellite observations, Prog. Oceanogr., 26, 357-402, 1991.

Varela, R. I. Á., Santos, F., de Castro, M., and GómezGesteira, M., Has upwelling strengthened along worldwide coasts over 1982-2010?, Sci. Rep.-UK, 5, 10016, https://doi.org/10.1038/srep10016, 2015.

Wang, C. and Zhang, L.: Multidecadal Ocean Temperature and Salinity Variability in the Tropical North Atlantic: Linking with the AMO, AMOC, and Subtropical Cell, J. Climate, 26, 61376162, https://doi.org/10.1175/JCLI-D-12-00721.1, 2013.

Wittenberg, A. T.: Are historical records sufficient to constrain ENSO simulations, Geophys. Res. Lett., 36, L12702, https://doi.org/10.1029/2009GL038710, 2009.

Yamamoto, A. and Palter, J. B.: The absence of an Atlantic imprint on the multidecadal variability of wintertime European temperature, Nat. Commun., 7, 10930, https://doi.org/10.1038/ncomms10930, 2016.

Zeeberg, J., Corten, A., Tjoe-Awie, P., Coca, J., and Hamady, B.: Climate modulates the effects of Sardinella aurita fisheries off Northwest Africa, Fish. Res., 89, 65-75, 2008.

Zenk, W., Klein, B., and Schröder, M.: Cape Verde Frontal Zone, Deep-Sea Res., 38, S505-S530, 1991.

Zhang, W., Mei, X., Geng, X., Turner, A. G., and Jin, F.-F.: A Nonstationary ENSO-NAO Relationship Due to AMO Modulation, J. Climate, 32, 33-43, 2019. 